\title{
Saprolitization's Characteristics of Rare Earth Elements in Volcanic Regolith on Drill Core \#65 in Western Sulawesi, Indonesia
}

\author{
Shaban Godang ${ }^{1}$, Arifudin Idrus ${ }^{2 *}$, Fadlin ${ }^{3}$, Bambang Priadi ${ }^{4}$ and Nurcahyo Indro Basuki ${ }^{4}$ \\ ${ }^{1}$ Rare mineral and rare-earth minerals researcher \\ ${ }^{2}$ Department of Geological Engineering, Faculty of Engineering, Universitas Gadjah Mada \\ ${ }^{3}$ Study Program of Geological Engineering, Jenderal Soedirman University \\ ${ }^{4}$ Department of Geology, Institut Teknologi Bandung \\ *Corresponding author: Dr. Arifudin Idrus (arifidrus@ugm.ac.id)
}

\begin{abstract}
The enrichment of Rare Earth Elements (REEs) in regolith depends on greatly number of chemical weathering degree, the ability of the ion-adsorption on clay, precipitation of REEs, minimum uptake by plants, and minor REE leaching out by lessivage. The degree of chemical weathering depends on the decaying of four base weathering elements ( $\mathrm{Mg}, \mathrm{Ca}, \mathrm{Na}, \mathrm{K})$ in minerals and is relatively less dependent on the slow leaching of silica. Therefore, a study of regolith profile from weathering's Adang Volcanics (western Sulawesi, Indonesia) is performed to understand the relationship between degree of chemical weathering, nature migration of $R E E$ and the characteristics of saprolitization REEs. The result of drill core samples shows the increasing of degree of chemical weathering (Degree of Saprolitization; DOS) is equal to gradual increasing of alumina by saprolitization, and has also gradual increase in Fe-Ti-oxides by ferruginization; furthermore, there is also a gradual enrichment of REEs occurred in the saprolite zone on Adang Volcanics regolith. The enrichment of REEs in the saprolite zones (E and B horizons) is 2.73 times (TREY $=2,579 \mathrm{ppm}$, in avg) compared to the parent mafic trachytic rocks $(944 \mathrm{ppm})$ reveal the high adsorption ability on lateritic-ferruginous clay. The thickness of high concentration REEs $(2,435$ ppm, in avg) is starting from $A$ to $E$, and B-horizon which is about $5 \mathrm{~m}$. The ratio of LREE and HREE is $87.42 \%$ and $12.58 \%$, respectively in parent rock which indicates the genesis of rare-earth is more influenced by replacement of $\mathrm{Ca}^{2+}, \mathrm{Na}^{+}$ and $\mathrm{K}^{+}$in minerals of diopside, apatite and leucite/pseudoleucite rather than the substitution by zircon $\left(\mathrm{Zr}^{4+}\right)$.
\end{abstract}

Keywords - Rare Earth Elements (REEs), ion-adsorption clays, degree of chemical weathering, degree of saprolitization (DOS), laterite and regolith

\section{INTRODUCTION}

Saprolitization is the enriching process of clay minerals, oxide-elements $\left(\mathrm{Al}_{2} \mathrm{O}_{3}, \mathrm{Fe}\right.$-oxide, Ti-oxide, (Ni, Co)-oxide), heavy minerals (zircon, rutile, tourmaline), and trace elements ( $\mathrm{REE}, \mathrm{Th} / \mathrm{U}, \mathrm{Nb} / \mathrm{Ta}$ ) in the in situ weathering profile formed in the tropical/subtropical zone or on the condition of high humidity. Saprolitization is formed by a process of decaying the four base weathering elements $(\mathrm{Mg}, \mathrm{Ca}, \mathrm{Na}, \mathrm{K})$ that occur in igneous, metamorphic or sedimentary protoliths (Bates and Jackson, 1987; Bárdossy and Aleva, 1990; Graham, 1996; Allaby, 2008; Hamblin and Christiansen, 2003 and related references).

Saprolitization of the rare-earth elements (REE) in the granitic weathering profile is different from the saprolitization of $\mathrm{Ni} / \mathrm{Co}$ that formed in peridotite (ultramafic) weathering profile, since each of the REE and Ni/Co has different nature of migration. Like the lateritic-Ni profile which the nickel component in the event of leaching, the nickel will immigrate vertically and enrich in the C-horizon and upper bedrock, which commonly called as garnierite; whereas the lateriticREE weathering profile, possibly enriched by nature migration of REE in A-horizon (topsoil/pedolith), B-horizon (subsoil; clay-rich), C-horizon (partially altered) and upper bedrock.

Rare earth elements (REE/REEs) consist of 15 elements from $\mathrm{La}$ to $\mathrm{Lu}+\mathrm{Y}$ \{except Pm (promethium) is synthetic element, which does not naturally occur on earth\}, which are divided into light REE (LREE; La-Sm) and heavy REE (HREE; Eu-Lu+Y). Scandium (Sc) is not grouped into the 15 elements because it is found in different types of deposits (basically obtained from the ultramafic rocks) (Henderson, 1984; China Mineral Reserves Committee, 1986; Rare Earth Elements, intertek; Aide and Aide, 2012). Rare-earth is substitutional elements formed on minerals related to rockforming minerals along the magmatic evolution and/or in mantle metasomatism. In general, the substitution occurs in mineral elements containing ionic radii is not much different from ionic radii REEs and $\mathrm{Sc}$ (e.g. $\mathrm{Ca}^{2+}, \mathrm{Mn}^{2+}, \mathrm{Na}^{+}, \mathrm{Ti}^{3+/ 4+}$, $\mathrm{Zr}^{4+}$ and rare in $\mathrm{K}^{+}$) (Lesnov, 2010; Shannon, 1976; Scott and Pain, 2009; Randive et al., 2014). The distribution patterns of REEs in rock-forming minerals display on Fig. 3. REE-rich bearing rocks are usually found in association with alkaline to peralkaline igneous complexes, in pegmatites associated with alkaline magmas and/or in associated with 
carbonatite intrusives. REE deposits also commonly occur during hydrothermal process which are associated with alkaline magmatism, in garnet-bearing of metamorphic rocks and weathering process in the form of placers, carbonatite laterites, lateritic bauxite or lateritic soils (Chakhmouradian and Wall, 2012).

Laterites known as red/brown residual soil developed in humid, tropical, and subtropical regions of good drainage, are near-surface chemical weathering products developed on variable parent rocks (mafic/basaltic, sedimentary rocks, high Fe-granitoids, etc). Laterite is chemically characterized by the depletion of mobile-elements such as $\mathrm{Mg}, \mathrm{Ca}, \mathrm{Na}, \mathrm{K}$ (some $\mathrm{Si}$ ) and enrichment of immobile-elements such as $\mathrm{Al}, \mathrm{Fe}(\mathrm{o})$, Ti and some silica $\{\mathrm{Fe}(\mathrm{o})$ as $\mathrm{Fe}(\mathrm{oxidized})$; Babechuk et al., 2014\}. It contains of the components, particularly of Fe-Ti oxides, hydroxides and aluminum hydroxides or clay minerals (Bárdossy and Aleva, 1990; Graham, 1996; Allaby, 2008 and related references). REEs in lateritic profiles related to granitoids chemical weathering is found in ion-adsorption type deposits in southern China, Madagaskar, Brazil, Laos, Myanmar, Vietnam, Thailand, Malaysia, Indonesia, etc. (Wu et al., 1990; Kynicky et al., 2012; Rocha et al., 2013; Berger et al., 2014; Sanematsu et al., 2016; Idrus et al., 2017). In general, the ion-adsorption type deposit is specifically related to the granitic weathering that containing of low Fe-content $\left(\mathrm{Fe}_{2} \mathrm{O}_{3}(\mathrm{t})<7 \%\right)$, in which the ion-REE adsorbed by clay minerals (such as gibbsite, kaolinite, hollosite, smectite, illite) which is easily extracted in the field by using ammonium sulfate solution $\left\{\left(\mathrm{NH}_{4}\right)_{2} \mathrm{SO}_{4}\right\}$, resulting in ion exchangeable between clay-(ion REE) and ammonium sulfate. This type of deposit is often referred to as ion-exchangeable type REE deposit (Wu et al., 1990a; Yang et al., 2013).

$$
\begin{aligned}
& \text { clay }+\mathrm{REE}^{2+/ 3+/ 4+} \rightarrow \text { clay- }(\mathrm{REE}) \quad\{\text { ion- } R E E \text { adsorbed by clay minerals\} } \\
& 2 \text { clay- }(\mathrm{REE})+3\left(\mathrm{NH}_{4}\right)_{2} \mathrm{SO}_{4} \rightarrow 2 \text { clay- }\left(\mathrm{NH}_{4}\right) 3+(\mathrm{REE})_{2}\left(\mathrm{SO}_{4}\right)_{3} \quad\{\text { ion-exchangeable }\}
\end{aligned}
$$

(Moldoveanu and Papangelakis, 2014)

The most stable of rare-earth oxides are expressed in multi-oxides respectively expressed as $\mathrm{La}_{2} \mathrm{O}_{3}, \mathrm{CeO}_{2}, \mathrm{Pr}_{6} \mathrm{O}_{11}$, $\mathrm{Nd}_{2} \mathrm{O}_{3}, \mathrm{Sm}_{2} \mathrm{O}_{3}, \mathrm{Eu}_{2} \mathrm{O}_{3}, \mathrm{Gd}_{2} \mathrm{O}_{3}, \mathrm{~Tb}_{4} \mathrm{O}_{7}, \mathrm{Dy}_{2} \mathrm{O}_{3}, \mathrm{Ho}_{2} \mathrm{O}_{3}, \mathrm{Er}_{2} \mathrm{O}_{3}, \mathrm{Tm}_{2} \mathrm{O}_{3}, \mathrm{Yb}_{2} \mathrm{O}_{3}, \mathrm{Lu}_{2} \mathrm{O}_{3}$, and $\mathrm{Y}_{2} \mathrm{O}_{3}$ with total rare-earth multioxides as $\mathrm{TRE}_{\mathrm{x}} \mathrm{O}_{\mathrm{y}}\left(\mathrm{GB} / \mathrm{T}\right.$ 17417.1-2010; Voncken, 2016; see also in Table 2). In China mainland, $\mathrm{TRE}_{\mathrm{x}} \mathrm{O}_{\mathrm{y}}$ is often expressed as TREO. The present study is to deduce the relationship between degree of chemical weathering, nature migration of REE and the characteristics of saprolitization REEs in regolith profile from weathering Adang Volcanics in Mamuju district, western Sulawesi, Indonesia.

\section{ANALYTICAL METHODS}

Bulk-rock geochemical analyses of major oxides, trace elements and REE of representative drill cores of trachytic parent rock and laterite samples were carried out in Intertek Laboratories in Jakarta by using X-ray fluorescence + LOI (XRFL) and four acids digest with method ICP-MS 4A/OM10 (with a lower detection limit for trace elements) and ICPMS 4A/MS11 (specific to REE) assay methods. Bulk powder X-ray diffraction (XRD) analysis was conducted at Universitas Gadjah Mada (Indonesia). Scanning Electron Microscopy (SEM) analysis was done at the University of Western Australia. The geochemical data were processed and plotted on various diagrams to elucidate the geochemical behavior and degree of saprolitization of the Adang volcanic regolith.

\section{FIELD LATERITE PROFILES}

The metasomatic mafic trachytic rock of Adang Volcanics is silica undersaturated rock, which was formed from extensional continental within-plate, that mostly consists of leucite/pseudoleucite, green diopside/augite/aegirine, phlogopite and groundmass (e.g. apatite, titano-hematite, magnetite, barite, sodalite, nepheline, microlite) (Godang et al., 2016). The laterites distributed in Mamuju and Mamasa districts (western Sulawesi) are derived by tropical weathering with the rainwater $\mathrm{pH} \sim 6.5$ (the current $\mathrm{pH}$ condition) from mid to late miocene mafic trachytic (Ratman and Atmawinata, 1993). Laterite profiles mostly composed of clay-rich and Fe-Ti-oxides (e.g. halloysite, smectite, leucite, titano-hematite, hematite, goethite, paragonite), and on the XRD analysis shows a relatively low intensity (Y-axis has a value about 25-240 cps), which ensures the absence of free quartz on lateritic soils (see in Fig. 5). The saprolite of REEs can be recognized starting from the upper part of the laterites regolith. The thickness of the laterite profiles accompanied by REEs is about $5 \mathrm{~m}$ (Fig. 2b).

\section{ANALYTICAL RESULTS}

Referring to the data on Table 1, there is a significant change in major elements during the chemical weathering process of $\mathrm{MgO}, \mathrm{CaO}, \mathrm{Na}_{2} \mathrm{O}$ and $\mathrm{K}_{2} \mathrm{O}$ which show the sequential decrease of $\mathrm{MgO}$ from parent rock $4.62 \%$ to laterite $0.24 \%, \mathrm{CaO}(7.25 \%$ to $0.01 \%), \mathrm{Na}_{2} \mathrm{O}(5.65 \%$ to $0.02 \%), \mathrm{K}_{2} \mathrm{O}(1.01 \%$ to $0.34 \%)$ and the increase of alumina $\left(\mathrm{Al}_{2} \mathrm{O}_{3}\right.$; $13.07 \%$ to $\sim 26.50 \%$, about 2 times), Fe-oxides $\left\{\mathrm{Fe}_{2} \mathrm{O}_{3}(\mathrm{t}) ; 10.10 \%\right.$ to $25 \%, 2.5$ times $\}, \mathrm{TiO}_{2}(1.56 \%$ to $3.6 \%, 2.3$ times). These data collection indicates a strong weathering condition. The increasing number of immobile-elements (Al-Fe(o)$\mathrm{Ti})$ and decreasing number of mobile-elements $(\mathrm{Mg}-\mathrm{Ca}-\mathrm{Na}-\mathrm{K})$ during the weathering process are comprised into ternary weathering diagram (Fig. 8). The diagram shows the degree of chemical weathering which referred as Degree of Saprolitization (DOS) as new developed model. The diagram is read from $\mathrm{C}$ to $\mathrm{A}\{0 \%$ to $100 \%$ of $\left.\mathrm{Al}_{2} \mathrm{O}_{3}+\mathrm{Fe}_{2} \mathrm{O}_{3}(\mathrm{t})+\mathrm{TiO}_{2}\right\}$. This new weathering diagram is created by using four base weathering elements $(\mathrm{Mg}, \mathrm{Ca}, \mathrm{Na}, \mathrm{K})$ 
which involves the rock forming minerals from mafic until felsic rocks, and has considered the presence of alumina, Fe and Ti-oxides in residual soil, so that the model can be used for all chemical weathering of rocks either orogenic and anorogenic protoliths. The conversion of ternary DOS diagram to logarithmic binary DOS diagrams is shown in Figures 9, 10 and 11 .

Plot in Fig. 7 shows five weathered samples fall in laterite field are relatively strong towards $\mathrm{Al}_{2} \mathrm{O}_{3}\left(\mathrm{Al}_{2} \mathrm{O}_{3}>\right.$ $\mathrm{Fe}_{2} \mathrm{O}_{3}(\mathrm{t})$, in $\mathrm{wt} \%$ ) and plot in Fig. 10 shows an oxidation trend (ferruginization) in weathered samples. The result of a combination of both diagram models can be referred to as lateritic-ferruginous clay. On Fig. 12a at the right column shows the order of relative mobility is $\mathrm{Na}>\mathrm{Ca}>\mathrm{Mg}>\mathrm{K}>\mathrm{Si}$, while the immobility elements $\mathrm{Al}$, Fe and $\mathrm{Ti}$.

At the point of drilling zone \#65, it appears the enrichment of REE in weakly weathered rock (depth 6-7m) and significant enrichment in lateritic profiles (depth $1-5 \mathrm{~m}$ ) is respectively 1.86 times and 2.58 times \{TREY parent rock: 944 ppm; weakly weathered (avg): $1,757 \mathrm{ppm}$; lateritic profiles (avg): 2,436 ppm. Saprolitization of REEs on the weathering of Adang Volcanics occurs in the upper part of the lateritic regolith to about $5 \mathrm{~m}$ depth (Figures 12a,b-13).

The percentage of LREE and HREE on the parent rock is $87.42 \%$ and $12.58 \%$, while on five lateritic samples LREE $83.15 \%$ and HREE $16.85 \%$. The increase of HREE on lateritic profiles is caused by negative Ce-anomaly in sample T03, T04 and T05 $(\mathrm{dCe}=0.66-0.80<1.00 ;$ Fib 12b).

\section{INTERPRETATION OF RESULTS}

The analytical results on various diagrams have been plotted and drawn in a diagram and sketch to recognize the degree of chemical weathering on rock, and to elucidate the characteristics of saprolitization in regolith profile.

The sequence of relative mobility is $\mathrm{Na}>\mathrm{Ca}>\mathrm{Mg}>\mathrm{K}>\mathrm{Si}$ and the immobility elements $\mathrm{Al}$, Fe and Ti. It can be explained that the sequence of weathering elements of the four base weathering elements $(\mathrm{Mg}, \mathrm{Ca}, \mathrm{Na}, \mathrm{K})$ in the rock does not necessarily correspond to the order $\mathrm{Mg}>\mathrm{Ca}>\mathrm{Na}>\mathrm{K}$ (Goldich's weathering series; Goldich, 1938), because the four weathering elements can occur first on $\mathrm{Na}$ or $\mathrm{Ca}$ compared to $\mathrm{Mg}$, $\mathrm{K}$ or vice versa, depending on how strong the bonds of the four elements are in minerals (such as $(\mathrm{Mg}, \mathrm{Ca})$-pyroxene, $(\mathrm{Mg}, \mathrm{Ca}, \mathrm{Na})$-amphibole group, $(\mathrm{Mg})-\mathrm{biotite},(\mathrm{Ca}, \mathrm{Na}, \mathrm{K})$ feldspar group), acid/non-acid rain and local temperatures can also affect the weathering sequence.

$$
\begin{array}{lc}
\mathrm{Na}>\mathrm{Ca}>\mathrm{Mg}>\mathrm{K}>\mathrm{Si}>\mathrm{Al}=\mathrm{Fe}=\mathrm{Ti} & \text { (in this study, Fig. 12a) } \\
\mathrm{Ca}>\mathrm{Na}>\mathrm{Mg}>\mathrm{K}>\mathrm{Si}>\mathrm{Al}=\mathrm{Fe} & \text { (Polynov, 1937) }
\end{array}
$$

The pathways of formation of secondary minerals, ionic rare-earth, and mechanism of REE enrichment in lateritic profiles from mafic trachytic Adang Volcanics can be proposed as follows:

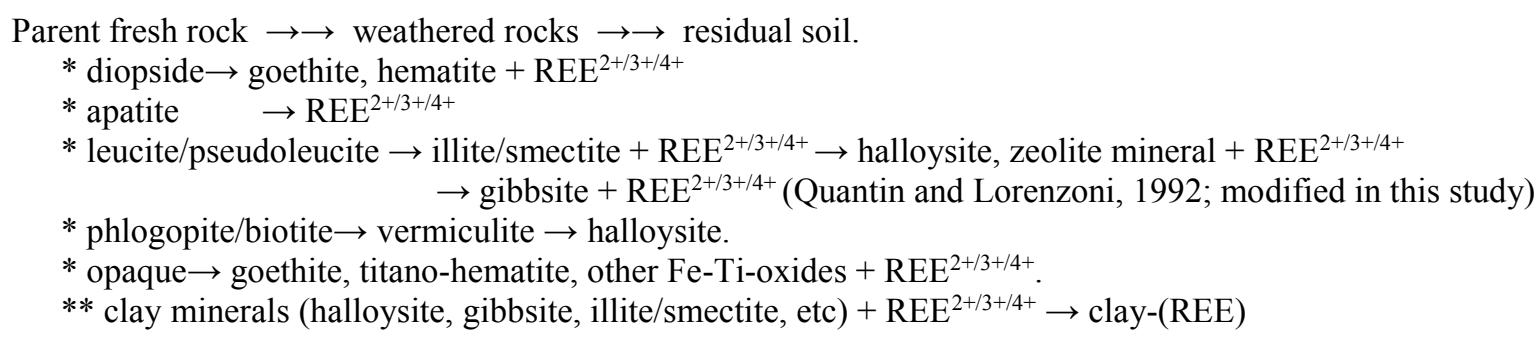

The ternary DOS diagram in Fig. 8 shows the boundary of unweathered/unaltered for mafic rocks is DOS of $<50 \%$, while for felsic rocks (granitic/rhyolitic) is DOS of $<55 \%$. Weak weathering (weakly saprolitization) is limited by $50 \%<\mathrm{DOS}<65 \%$, intermediate weathering (moderately saprolitization; $65 \%<\mathrm{DOS}<85 \%$ ), strong weathering (strongly saprolitization; $85 \%<\mathrm{DOS}<=100 \%$ ). Plot results of Table 1 shows the samples T06 and T07 are weakly saprolitization (DOS $=54.79-58.30 \%$ ), while the samples T01-T05 show strongly saprolitization (DOS $>92.84 \%$ ).

In the Binary DOS of Alumina diagram (Fig. 9) present the ideal increase of DOS is equal to the gradual increase of alumina by saprolitization (see also Fig. 6 upper part). The diagram showed an increase in alumina from fresh rock $(\mathrm{Al} 2 \mathrm{O} 3=13.07 \% \mathrm{wt})$ to lateritic $\left(\mathrm{Al}_{2} \mathrm{O}_{3}=23.29-26.81 \% \mathrm{wt}\right)$ by 1.93 times (in avg). Fig. 10 shows the ferruginization trend by oxidation, concluded by the increasing of Fe-Ti-oxides from fresh rock $11.67 \%$ to lateritic $24.60-28.70 \%$ by 2.29 times (in avg).

Plot on Binary DOS of REEs diagram (Fig. 11) shows the gradual increase of REEs by saprolitization along with the increase of DOS. The increasing of REEs from fresh rock (TREY $=994 \mathrm{ppm}$ ) to weakly weathered (sample T07 $=1,472 \mathrm{ppm})$, lateritic saprolite $(\mathrm{T} 02-\mathrm{T} 05=2,196-2,930 \mathrm{ppm})$ and lateritic topsoil $(\mathrm{T} 01=1,861 \mathrm{ppm})$. Sample of T06 is weak weathered but has a high REE concentration (DOS $=54.79 \%, 2,043 \mathrm{ppm})$, the enrichment on T06 represents of precipitation of REEs that comes from the upper part of the ion-REE movement downward as precipitation. The rather high concentration of rare-earth in pedolith $(\mathrm{T} 01$; TREY $=1,860 \mathrm{ppm})$ indicates the topsoil contains only a little humus, organic materials and is relatively not contaminated with volcanic dust coming from elsewhere. It also implies the minimum uptake of REEs by plants and minor lessivage factor on topsoil (Figures 12a-13 and see also Fig. 6 lower part). 
SEM analysis in Fig. 4 shows the REEs formed in parent rock are very fine grains as a non-crystalline rare-earth \{unfractionated rare-earth elements; REE as replacement of $\mathrm{Ca}^{2+}, \mathrm{Na}^{+}$and $\mathrm{K}^{+}$? in non-REE minerals (e.g. diopside, apatite, leucite, titanite?)\}; However, the observation in SEM micrographs does not find crystalline rare-earth minerals such as monazite $\left((\mathrm{REE}, \mathrm{Th}) \mathrm{PO}_{4}\right)$, xenotime $\left(\mathrm{YPO}_{4}\right)$, and the zircon mineral $\left(\mathrm{ZrSiO}_{4}\right)$ is also not observed in SEM analysis because the mineralogy of the groundmass is too fine grained to resolve.

The replacement of rare-earth in the minerals like as diopside, apatite, leucite/pseudoleucite, titanite is as follows:

* diopside: $\mathrm{Ca}(\mathrm{Mg}, \mathrm{Fe}) \mathrm{Si}_{2} \mathrm{O}_{6} \rightarrow(\mathrm{Ca}, \mathrm{LREE})(\mathrm{Mg}, \mathrm{Fe}) \mathrm{Si}_{2} \mathrm{O}_{6} \quad$ \{diopside carry LREE

* apatite (phosphorite): $(\mathrm{Ca}, \mathrm{Ba}, \mathrm{Pb}, \mathrm{Sr}, \mathrm{etc})_{5}\left(\mathrm{PO}_{4}, \mathrm{CO}_{3}\right)_{3}(\mathrm{~F}, \mathrm{Cl}, \mathrm{OH}) \rightarrow([\mathrm{Ca}, \mathbf{L R E E}], \mathrm{Ba}, \mathrm{Pb}, \mathrm{Sr}, \mathrm{etc})_{5}\left(\mathrm{PO}_{4}, \mathrm{CO}_{3}\right)_{3}(\mathrm{~F}, \mathrm{Cl}, \mathrm{OH}) \quad\{$ apatite carry $\mathrm{LREE}\}$

* leucite/pseudoleucite:

$(\mathrm{K}, \mathrm{Na}) \mathrm{AlSi}_{3} \mathrm{O}_{8} \rightarrow(\mathrm{K}, \mathrm{Na}, \mathbf{L R E E}) \mathrm{AlSi}_{3} \mathrm{O}_{8} \quad$ \{leucite/pseudoleucite carry LREE $\}$

$*$ titanite/sphene: $\mathrm{CaTiO}\left(\mathrm{SiO}_{4}\right) \rightarrow(\mathrm{Ca}, \mathbf{L R E E}) \mathrm{TiO}\left(\mathrm{SiO}_{4}\right) \quad\{$ titanite carry LREE\}

\section{DISCUSSION}

Plotting results in figures 11,13 and 12a,b show the gradual enrichment of REEs on lateritic-ferruginous clay which reflects the increase of DOS by REEs ion-adsorption on clay in saprolite zone. The high enrichment REEs in lateritic profiles (depth $2-5 \mathrm{~m}$ ) is about 2.73 times from parent rock which directly reflects the high ability of ion-adsorption on lateritic-ferruginous clay. This may be caused by the grains of REEs are too fine and the availability of unfractionated REEs in parent rock minerals (such as diopside, apatite, leucite; Fig. 4) that make it easier to be leached into ionic $\mathrm{REE}^{2+/ 3+/ 4+}$ during weathering and dissolved in near-neutral $\mathrm{pH} \sim 6.5$ of soil water.

The existence of the ratio of laterite/parent rock for $\mathrm{Na}_{2} \mathrm{O}$ and $\mathrm{CaO}$ is practically close to 0.00 (see in Table 2) in which the cation of $\mathrm{Na}^{+}$dan $\mathrm{Ca}^{2+}$ are as replacement of LREE, and consider to the rare replacement of LREE by $\mathrm{K}^{+}$, hence it could be concluded the maximum enrichment of REEs in the saprolite zone is about 3 times from the parent rock. If it is more than 3 times, then it could be interpreted that the rare-earth has been enriched through the lessivage that comes from other places carried in by groundwater flow or perhaps the enrichment of those rare-earth is formed from the weathering between the mixing of metasomatic mafic magma and rich REE of paleosol when magmatism occurred (see in Fig. 3d from paper Godang et al., 2016).

Referring to the data in Table 2, the ratio of laterite/parent rock for major oxides respectively $\mathrm{Na}_{2} \mathrm{O}=0.01, \mathrm{CaO}=$ $0.01, \mathrm{MgO}=0.11, \mathrm{~K}_{2} \mathrm{O}=0.68, \mathrm{SiO}_{2}=0.67$. The ratio of four base weathering elements $(\mathrm{Mg}, \mathrm{Ca}, \mathrm{Na}, \mathrm{K})$ shows they almost have been leaching out from the rock which characterized by DOS $>92.84 \%$ (strong weathering); and in addition that the silica mineral carrier for rare-earth like zircon $\left(\mathrm{ZrSiO}_{4}\right)$ does not carry REE, so that the slow leaching of silica $\left(\mathrm{SiO}_{2}\right)$ is relatively less affecting an increase of REE concentrations in residual soil.

The ratio of LREE and HREE (87.42\% and 12.58\%) shows LREE is stronger than HREE in the parent rock, which indicates the rare-earth is more influenced by replacement of $\mathrm{Ca}^{2+}, \mathrm{Na}^{+}, \mathrm{K}^{+}$? in minerals of diopside, apatite and leucite/pseudoleucite (Lesnov, 2010; Chakhmouradian and Wall, 2012; see also in Fig. 3), and in this study the presence of zircon practically does not carry the HREE.

The rare-earth spidergram shows the positive enrichment of REEs (in total REE) but has a negative Ce anomaly (dCe $<1.00$ ) for laterite samples T03--T06 (Fig. 14). The presence of negative Ce anomaly indicates the occurrence of lessivage (horizontal leaching) in the depth between $3 \mathrm{~m}$ to $6 \mathrm{~m}$ and carrying out of some Ce-ion following the groundwater flow (Fig. 12b). In general, the Ce anomaly in weakly weathered rock, mafic laterites or lateritic granitoid weathering is common, due to the relatively easy leaching of Ce-ion compared to the other 14-ions rare-earth elements, and it carries in/out by groundwater flow. The Ce anomaly has no direct effect on enrichment/depletion of REEs mineralization in laterites; however, more attention is usually given to the distribution of LREE \& HREE (Fig. 12b; see also the bottom table of Table 2). The rare-earth distribution trend in normalized diagram (Fig. 14) displays Eu negative anomaly that reflects the presence of a mineral constituent of rocks such as apatite, diopside in which each has a trend of negative Eu characteristics (see in Fig.3).

Ion-adsorption on ferruginous clay in lateritic Adang Volcanics is not directly referred to the ion-exchangeable type REE deposit because the term of "ion-exchangeable type REE deposit" should go through a series of extraction trials and easily in-situ extracted with chemical reagent such as ammonium sulfate solution (Wu et al., 1990a; Yang et al., 2013).

\section{CONCLUSION}

Our study of the relationship between degree of chemical weathering and the characteristics of saprolitization REEs in regolith profile has obtained the following results:

1. The increasing degree of chemical weathering ("degree of saprolitization (DOS)") affects the increase of immobileelement geochemistry such as $\mathrm{Al}, \mathrm{Fe}(\mathrm{o})$, Ti (+ LOI) and also enriched in rare-earth elements. The increase of DOS equals to the gradual increase of alumina, and in this study has gradual increase also in Fe-Ti-oxides; furthermore, there is equally reflected in the gradual enrichment of REEs in the saprolite zone on Adang Volcanics regolith. 
2. The enrichment of REEs in the saprolite zone (E and B horizons) is by 2.73 times $(2,579$ ppm, in avg) compared to the parent mafic trachytic. The thickness of high concentration REEs $(2,435 \mathrm{ppm}$, in avg) is starting from A to E, Bhorizon which is about $5 \mathrm{~m}$. The C-horizon has $2 \mathrm{~m}$ of thickness with concentration 1,757 ppm (in avg). Therefore, A-E-B and upper C-horizons are the potential targets for the ore body.

3. The strong enrichment of REEs in the regolith is affected by high ability of ion-adsorption on lateritic-ferruginous clay, minimum uptake by plants, and minor REE leaching out by lessivage.

4. The ratio of LREE and HREE is $87.42 \%$ and $12.58 \%$ in parent rock which indicate the genesis of rare-earth is more influenced by replacement of $\mathrm{Ca}^{2+}, \mathrm{Na}^{+}, \mathrm{K}^{+}$? from minerals of diopside, apatite and leucite/pseudoleucite rather than the substitution by zircon $\left(\mathrm{Zr}^{4+}\right)$.

\section{ACKNOWLEDGEMENTS}

The authors express their gratitude to the Management of PT. LTJ Global Jaya for giving a permit to conduct the fieldwork for this study. We are thankful to Prof. Mega Fatimah Rosana (Faculty of Geological Engineering, Padjadjaran University) for her constructive inputs and comments. A sincere thanks goes to Dr. Bert De Waele for SEM analysis at University of Western Australia.

\section{REFERENCES}

Abedini, A. and Calagari, A.A., 2014. REE geochemical characteristics of titanium-rich bauxites: the Permian Kanigorgeh horizon, NW Iran. Turkish Journal of Earth Sciences, vol. 23, p. 513-532

Aide, M.T., and Aide, C., 2012, Rare earth elements: Their importance in understanding soil genesis: International Scholarly Research Network, ISRN Soil Science 2012, Article ID 783876, 11 p.

Aleva, G.J.J., 1994. Laterites: Concepts, Geology, Morphology and Chemistry. Wageningen, the Netherlands: ISIRC, ISBN: 90.6672.053.0., $169 \mathrm{p}$.

Allaby Michael, 2008 ( $3^{\text {rd }}$ Ed). A Dictionary of Earth Sciences. Oxford University Press, $663 \mathrm{p}$

Anand, R.R., Paine, M.D. and Smith, R.E., 2002. Genesis, classification and atlas of ferruginous materials, Yilgarn Craton. (C) CSIRO Exploration and Mining, $91 \mathrm{p}$.

Aubert, D., Stille, P. and Probst, A., 2001. REE fractionation during granite weathering and removal by waters and suspended loads: Sr and Nd isotopic evidence. Geochimica et Cosmochimica Acta, Vol. 6. p.387-406

Babechuk, M.G. and Kamber, B.S., 2013. The Flin Flon paleosol revisited. Can. J. Earth Sci. vol. 50: p. 1223-1243

Babechuk, M.G., Widdowsonc, M., Kamber, B.S., 2014. Quantifying chemical weathering intensity and trace element release from two contrasting basalt profiles, Deccan Traps, India. Elsevier, Chemical Geology, vol. 363, p. 56-75.

Bao, Z., and Zhao, Z., 2008. Geochemistry of mineralization with exchangeable REY in the weathering crusts of granitic rocks in South China: Ore Geology Review, vol. 33, p. 519-535.

Bárdossy, G. and Aleva, G.J.J., 1990. Lateritic Bauxites. Developments in Economic Geology, 27, Elsevier, AmsterdamOxford-New York-Tokyo, $624 \mathrm{p}$.

Berger, A., Janots, E., Gnos, E., Frei, R. and Bernier, F., 2014. Rare earth element mineralogy and geochemistry in a laterite profile from Madagascar. Applied Geochemistry, Vol. 41, p. 218-228

Bunzli, J-C.G. and Pecharsky, V.K., 2016. Handbook on the Physics and Chemistry of Rare Earths Volume 49. Elsevier, $473 \mathrm{p}$

Castor, S.B., and Hedrick, J.B., 2006. Rare earth elements. (in Industrial Minerals Volume, 7th edition: Society for Mining, Metallurgy, and Exploration, Littleton, Colorado, p. 769-792).

Chakhmouradian, A.R. and Wall, F., 2012. Rare Earth Elements: Minerals, Mines, Magnets (and More). Elements, vol. 8, No. 5, p.333-340

Chen, T., Ai, H., Yang, M.X., Zheng, S. and Liu, Y.G., 2011. Brownish Red Zircon from Muling, China. Gems and Gemology, p. 36-41

China Mineral Reserves Committee, 1986. Handbook of industrial minerals product requirement and references. China Geological Publishing House, p. 178-190

Cocker, M.D., 2012. Lateritic, supergene rare earth element (REE) deposits. Proceedings of the 48th Annual Forum on the Geology of Industrial Minerals Arizona. Chapter 4, p.1-18.

Carroll Dorothy, 1970. Rock Weathering. (C) Plenum Press, New York, $213 \mathrm{p}$

Eggleton, R.A., 2001. Regolith Glossary: Surficial Geology, Soils and Landscapes.

Evans, C.H., 1996. Episodes from the History of the Rare Earth Elements. Kluwer Academic Publishers, Vol. 15, $354 \mathrm{p}$

Hamblin, W.K. and Christiansen, E.H., 2003 (10 ${ }^{\text {th }}$ Ed). Earth's Dynamic Systems. Prentice Hall, p. 248-273

Hamdan, J., Peli, M. and Ruhana, B., 2003. Weathering Behaviour of a Basaltic Regolith from Pahang, Malaysia. C Universiti Putra Malaysia Press. PertanikaJ. Trap. Agric. Sci. Vol. 26, No. 2, p.79 - 88

GB/T 17417.1-2010. China Method for chemical analysis of rare earth ores. Part 1: Determination of rare earths. https://www.codeofchina.com

Godang, S., Fadlin, Priadi, B., 2016. Geochemical Signatures of Potassic to Sodic Adang Volcanics, Western Sulawesi: Implications for Their Tectonic Setting and Origin. Indonesian Journal on Geoscience Vol. 3 No. 3, p. 195-214

Goldich, Samuel S., 1938. A study in rock weathering. Journal of Geology, vol.46, p.17-58. 
Graham, R.L., 1996 (2nd ed). Dictionary of Mining, Mineral, \& Related Terms. U.S. Bureau of Mines, 3660 p

Henderson, P., 1984. Rare Earth Element Geochemistry. Elsevier, p.vi

Hoshino, M., Sanematsu. K. and Watanabe, Y., 2016: REE Mineralogy and Resources. (in Handbook on the Physics and Chemistry of Rare Earths Volume 49, Chapter 279 (Bunzli, J-C.G. and Pecharsky, V.K., p. 129-291

Hsu Wei-biao., 2003. Rare earth element geochemistry and petrogenesis of Miles (IIE) silicate inclusions. Geochimica et Cosmochimica Acta, Vol. 67, No. 24, p. 4807-4821

http://www.intertek.com/WorkArea/DownloadAsset.aspx?id=48006

Idrus, A., Fadlin and Verdiansyah, O., 2017. Rare Earth Elements (REE) and Scandium (Sc) exploration on weathered Mamasa granitoid complex (western Sulawesi). Unpublished Report, $149 \mathrm{p}$.

Kabata-Pendias Alina, 2014 (4th Ed). Trace Elements in Soils and Plants. CRC Press Taylor and Francis Group, LLC. $488 \mathrm{p}$

Kynicky, J., Smith, M.P., Xu, C., 2012. Diversity of rare earth deposits: the key example of China. Elements, Vol. 8, p. 361-367

Lesnov, F.P., 2010. Rare Earth Elements in Ultramafic and Mafic Rocks and their Minerals - Main types of rocks. Rockforming minerals. (C) 2010 Taylor \& Francis Group, London, UK, 587 p

Lutgens, F.K. and Tarbuck, E.J., 2012 (11th Ed). Essentials of geology, Pearson Prentice Hall, 138 p.

Maulana, A., Yonezu, K. and Watanabe, K., 2014. Geochemistry of Rare Earth Elements (REE) in the Weathered Crusts from the Granitic Rocks in Sulawesi Island, Indonesia. Journal of Earth Science, Vol. 25, No. 3, p. 460-472

McDonough, W.F. and Sun, S.S., 1995. The composition of the Earth. Chemical Geology, vol.120, p. 223-253

Mcqueen, Kenneth-George, 2006. Unravelling the regolith with geochemistry. Regolith 2006 - Consolidation and Dispersion of Ideas

Moldoveanu, G.A. and Papangelakis, V.G., 2014. An overview of rare-earth recovery by ion-exchange leaching from ion-adsorption clays of various origins. Mineralogical Magazine, February 2016, Vol. 80, No.1, p. 63-76

Nesbitt, H.W. and Wilson, R., 1992. Recent chemical weathering of basalts, American Journal of Science, Vol.292, p.740-777.

Nesbitt, H.W. and Young, G.M., 1984. Prediction of some weathering trends of plutonic and volcanic rocks based on thermodynamic and kinetic considerations. Geochimica Cosmochimica Acta, Vol. 48, p. 1523-1534.

Polynov, B.B., 1937. Cycle of Weathering. Murby, 220p

Quantin, P. and Lorenzoni, P., 1992. Weathering of leucite to clay minerals in tephrites of the Vico volcano. Miner. Petrogr. Acta. Vol. XXXV-A, p. 289-296

Randive, K., Kumar, J.V., Bhondwe, A. and Lanjewar, S., 2014. Understanding the Behaviour of Rare Earth Elements in Minerals and Rocks. Gond. Geol. Mag., Vol. 29 (1 and 2)

Ratman, N. and Atmawinata, S., 1993. Geological map of the Mamuju Quadrangle, Sulawesi, (scale 1:250.000), Geological research and Development Centre, Bandung.

Retallack, G.J., 2010. Lateritization and Bauxitization Events. Economic Geology, vol. 105, p. 655-667.

Rocha, A., Schissel, D., Sprecher, A., de Tarso, P. and Goode, J., 2013. Process development for the Serra Verde weathered crust elution-deposited rare earth deposit in Brazil. Proceedings of the 52rd Conference of Metallurgists (COM2013), Metallurgical Society of the Canadian Institute of Mining, Metallurgy and Petroleum (MetSoc-CIM), Montreal, Canada.

Rudnick, R.L. and Gao, S., 2003. Composition of the Continental Crust (in Treatise on Geochemistry, Volume 3, Elsevier Ltd., Radarweg 29, 1043 NX Amsterdam, the Netherlands. First edition 2010. p. 131-196)

Salters, V.J.M., and Stracke, A., 2004. Composition of the depleted mantle. G3 (Geochemistry, Geophysics, Geosystems) Vol 5, No.5, p. 1-27

Sanematsu, K., Murakami, H., Watanabe, Y., Duangsurigna, S., Vilayhack, S., 2009. Enrichment of Rare Earth Element in Granitic Rocks and their Weathered Crusts in Central and Southern Laos. Bulletin of the Geological Survey of Japan, vol. 60, No.11-12, p.527-558

Sanematsu, K., Moriyama, T., Sotouky, L. and Watanabe, Y., 2011a. Laterization of basalts and sandstone associated with the enrichment of $\mathrm{Al}, \mathrm{Ga}$ and $\mathrm{Sc}$ in the Bolaven Plateau, southern Laos. Bulletin of the Geological Survey of Japan, Vol. 62, No.3/4, p. 105-129

Sanematsu, K., Kon, Y., Imai, A., Watanabe, K. and Watanabe, Y., 2011b. Geochemical and Mineralogical Characteristics of Ion-Adsorption Type REE Mineralization in Phuket, Thailand. Mineralium Deposita, vol. 48, No. 4, p. 437-451

Sanematsu, K. and Kon, Y., 2013. Geochemical characteristics determined by multiple extraction from ion-adsorption type REE ores in Dingnan County of Jiangxi Province, South China. Bulletin of the Geological Survey of Japan, vol. 64, No. 11/12, p. 313-330.

Sanematsu, K. and Watanabe, Y., 2016. Characteristics and Genesis of Ion Adsorption-Type Rare Earth Element Deposits. Rev. Econ. Geol. Vol.18, p.55-79

Sayyed, M.R.G., 2014. Lithological control on the mobility of elements during chemical weathering. Comunicações Geológicas, vol. 101, No.1, p.63-69

Schellmann, W., 1986. On the geochemistry of laterites. Chem. Erde, vol. 45, p.39-52 
Scott, K.M. and Pain, C.F., 2009. Regolith science. Springer, 473 p

Shannon, R.D., 1976. Revised effective ionic radii and systematic studies of interatomic distances in halides and chalcogenides. Acta Crystallographica, vol. A32, p.751-767.

Sun, S.S. and McDonough, W.F., 1989. Chemical and isotopic systematics of oceanic basalts: implications for mantle composition and processes. Geological Society, London, Special Publications; Vol. 42, p. 313-345

Taylor, S. R., and McLennan, S. M., 1985. The Continental Crustal: Its Composition and Evolution. Blackwell, Oxford, p. $697-719$

Voncken, J.H.L., 2016. The Rare Earth Elements: An Introduction. Springer Briefs in Earth Sciences, Springer, $125 \mathrm{p}$

Waele, B.D. and Muharam, 2014. Geological Interpretation of the Mamuju Rare Earth Mineral Prospect, West Sulawesi, Indonesia. PT. SRK Consulting Indonesia (Unpublished report), $50 \mathrm{p}$

Wang Deng-hong, Zhao Zhi, Yu Yang, Wang Cheng-hui, Dai Jing-jing, Sun Yan, et al., 2017. A Review of the Achievements in the Survey and Study of Ion-absorption Type REE Deposits in China. (Paper in Mandarin), Acta Geoscientica Sinica, Vol. 38 No.3, p.317-325

Watanabe, Y., Kon, Y., Echigo, T. and Kamei, A., 2016. Differential Fractionation of Rare Earth Elements in Oxidized and Reduced Granitic Rocks: Implication for Heavy Rare Earth Enriched Ion Adsorption Mineralization. Resource Geology Vol. 67, No. 1, p.35-52.

Weill, D.F. and Drake, M.J., 1973. Europium Anomaly in Plagioclase Feldspar: Experimental Results and Semiquantitative Model. Science, Vol. 180, No.4090, p.1059-1060

Wilford, J., 2011. Weathering intensity map of the Australian continent. AusGeo News 101, March 2011, p. 1-5

Worrall, F. and Pearson, D.G., 2001. Water-rock interaction in an acidic mine discharge as indicated by rare earth element patterns. Geochim. Cosmochim. Acta, vol. 65, p.3027-3040

Wu, C.Y., Huang, D.H., and Guo, Z.G., 1990a, REE geochemistry in the weathered crust of granites, Longnan area, Jiangxi Province: Acta Geologica Sinica, vol. 3, p. 193-210.

Wu, C.Y., Huang, D.H., Bai, G., and Ding, X.S., 1990b, Differentiation of rare earth elements and origin of granitic rocks, Nanling Mountain area. Acta Petrologica Mineralogica, vol.9, p.106-116 (in Chinese).

Yang, X.J., Lin, A.J., Li, X.L., Wu, Y.D., Zhou, W.B. and Chen, Z.H, 2013. China's ion-adsorption rare earth resources, mining consequences and preservation. Environmental Development, vol. 8, p. 131-136

Zhang, Z.H., 1990. A study on weathering crust ion adsorption type REE deposit, South China. Contrib. Geol. Miner. Resour. Res. vol. 5, p. 57-71 (in Chinese with English abstract). 


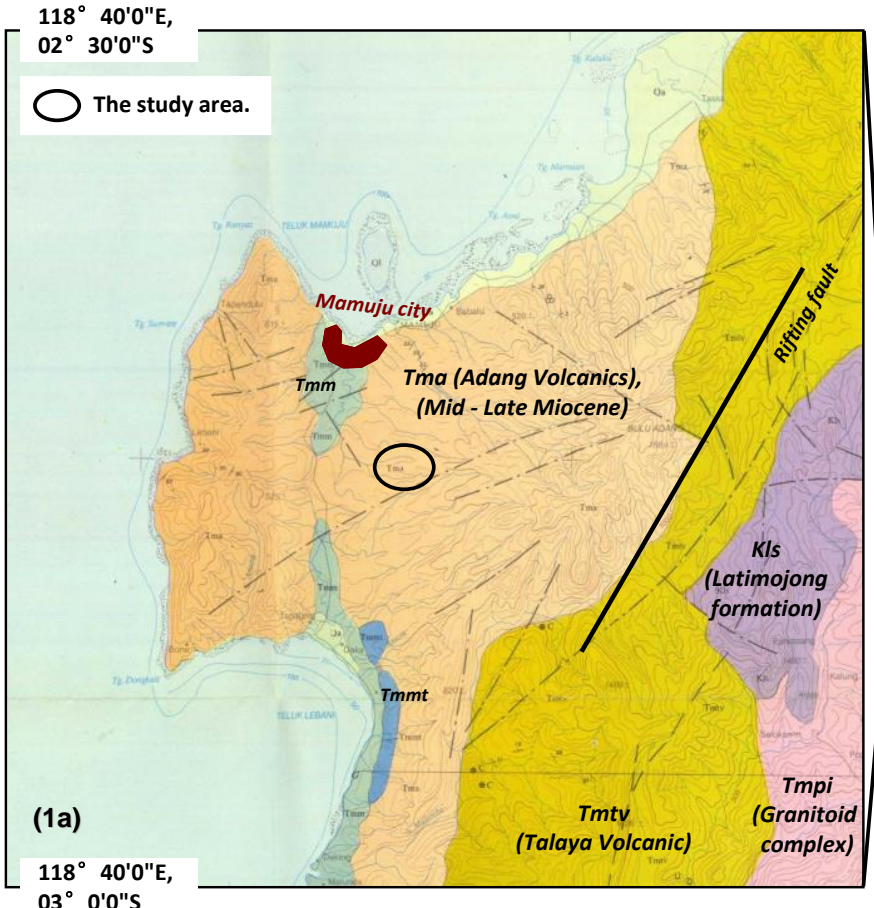

$119^{\circ} 10^{\prime} 0^{\prime \prime} \mathrm{E}$

$03^{\circ} 00^{\prime \prime S}$

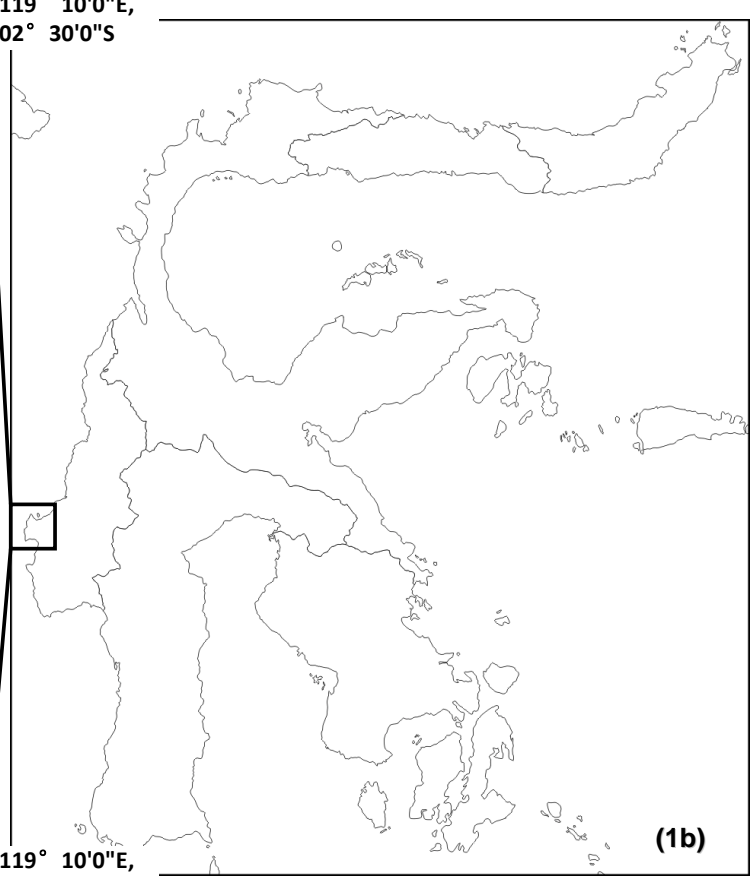

Figure: (1a). Geological map of western Sulawesi (Ratman and Atmawinata, 1993). Tmpi, Intrusive rocks (late miocene - pliocene); Tmtv, Talaya volcanic rocks (mid miocene-pliocene); Tmmt, Tapalang member of Mamuju formation (late miocene) composed of Reef limestone, fragmental limestone and marl; Tmm, Mamuju formation (late miocene) composed of marl, calcarenite, coralline limestone with tuff and sandstone intercalations, locally conglomerate; Tma, Adang volcanic rocks (mid-late miocene); Kls, Latimojong Formation (cretaceous). (1b). Map of Sulawesi, Indonesia
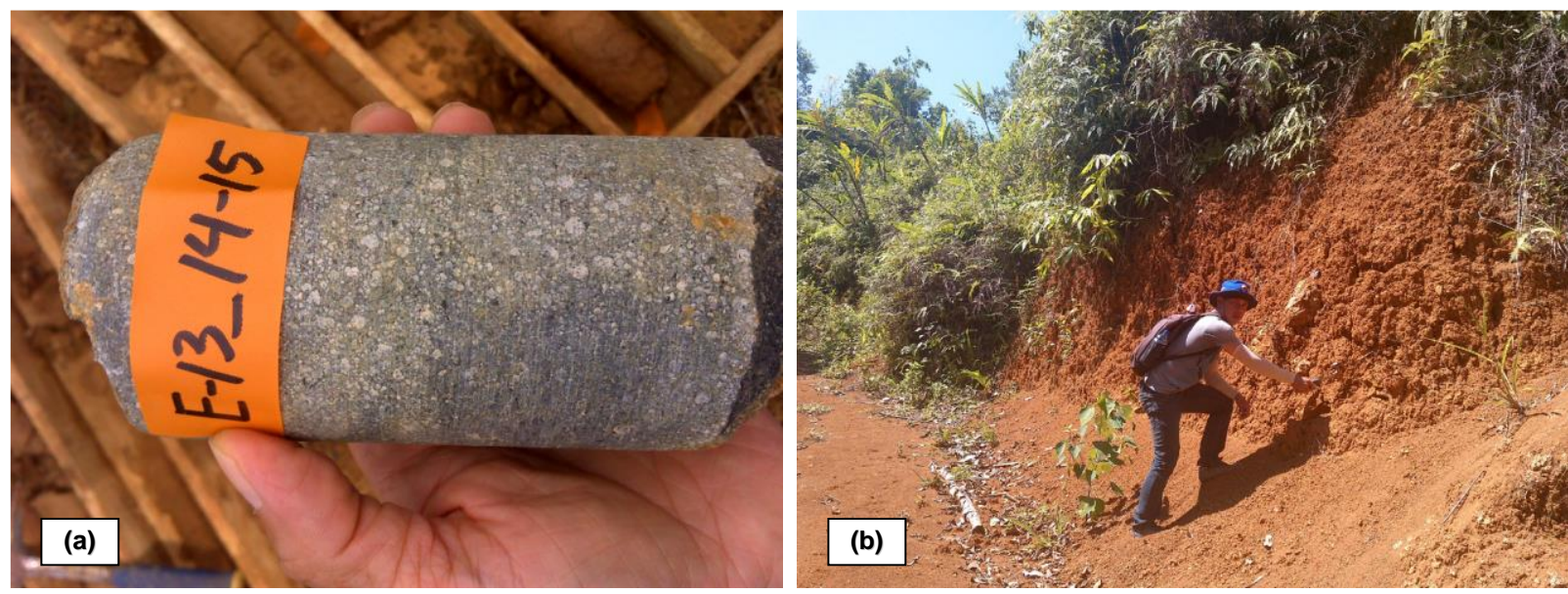

Figure 2. (2a) Trachytic Adang volcanics characterized by leucite phenocryst with trachytic texture (drill core samples), (2b) Tropical laterite profiles \{red (oxidized) soils\} from weathering mafic trachytic rock composed of clay-rich (e.g. halloysite, smectite) and Fe-Ti-oxides (e.g. titanohematite, goethite). 


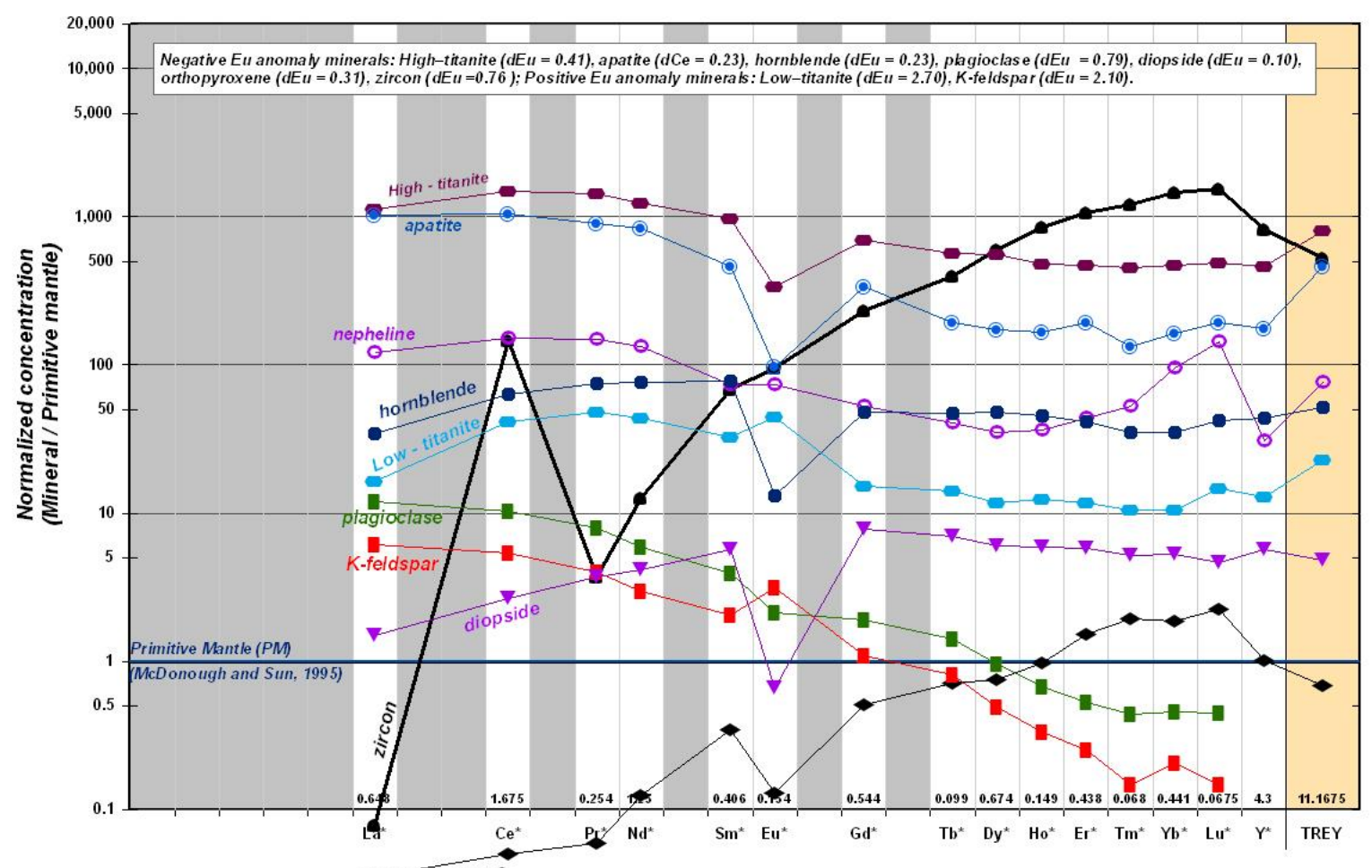

Figure 3: Primitive Mantê-qtîtqhápized REE distribution patterns for selected minerals, including orthopyroxene \& diopside (Hsu, 2003), hornblende-titanite-apatite (Watanabe et al., 2016), plagioclase \& orthoclase (Aubert, et al., 2001), zircon (Chen et al., 2011), http://georoc.mpch-mainz.gwdg.de/georoc/CompFiles.aspx\#rockfiles (nepheline)
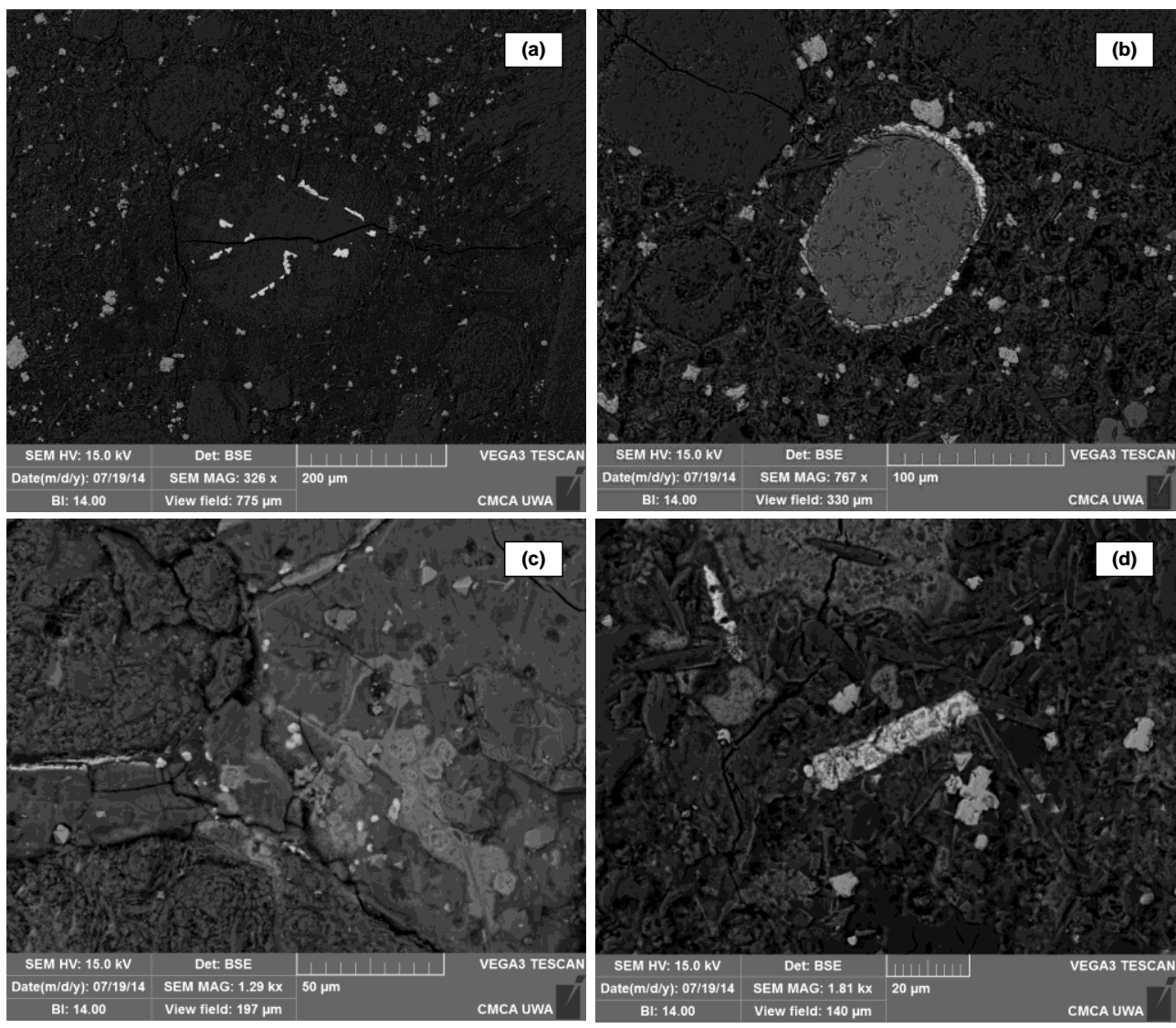

Figure 4: SEM-backscattered electron images show REEs occurrences in the study of parent mafic trachytic Adang Volcanics. The white spots contained of REEs, Th, Ca, Si, P, O. (a) REEs are fairly abundant in very fine grains form in the groundmass and in altered leucite. The rare-earth appears as replacement of $\mathrm{K}^{+} / \mathrm{Na}^{+}$. (b) REEs are fairly abundant in very fine grains form in the groundmass and rims of apatite as replacement of $\mathrm{Ca}^{2+}$. (c) REEs replace $\mathrm{Ca}^{2+}$ on diopside phenocrysts. They appear in very fine grains form and as non-crystalline REE. (d) REEs are fairly abundant in very fine grains form in the groundmass. 

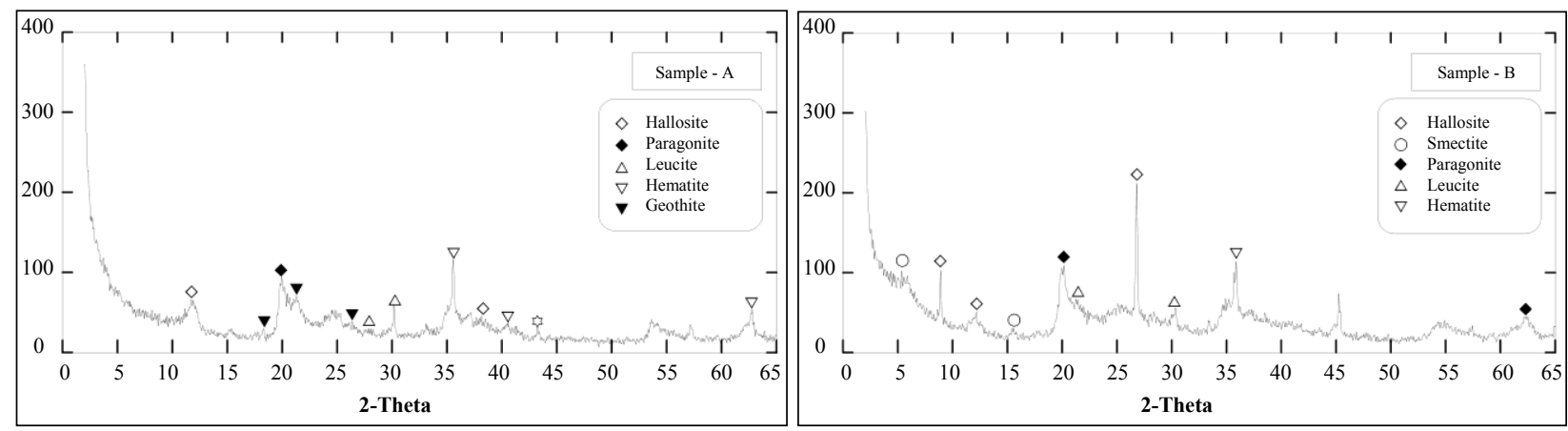

Figure 5 : Representative X-ray diffraction (XRD) micrographs of lateritic soil samples of Sample-A and Sample-B. The Y-axis is intensity, in cps (counts per second)

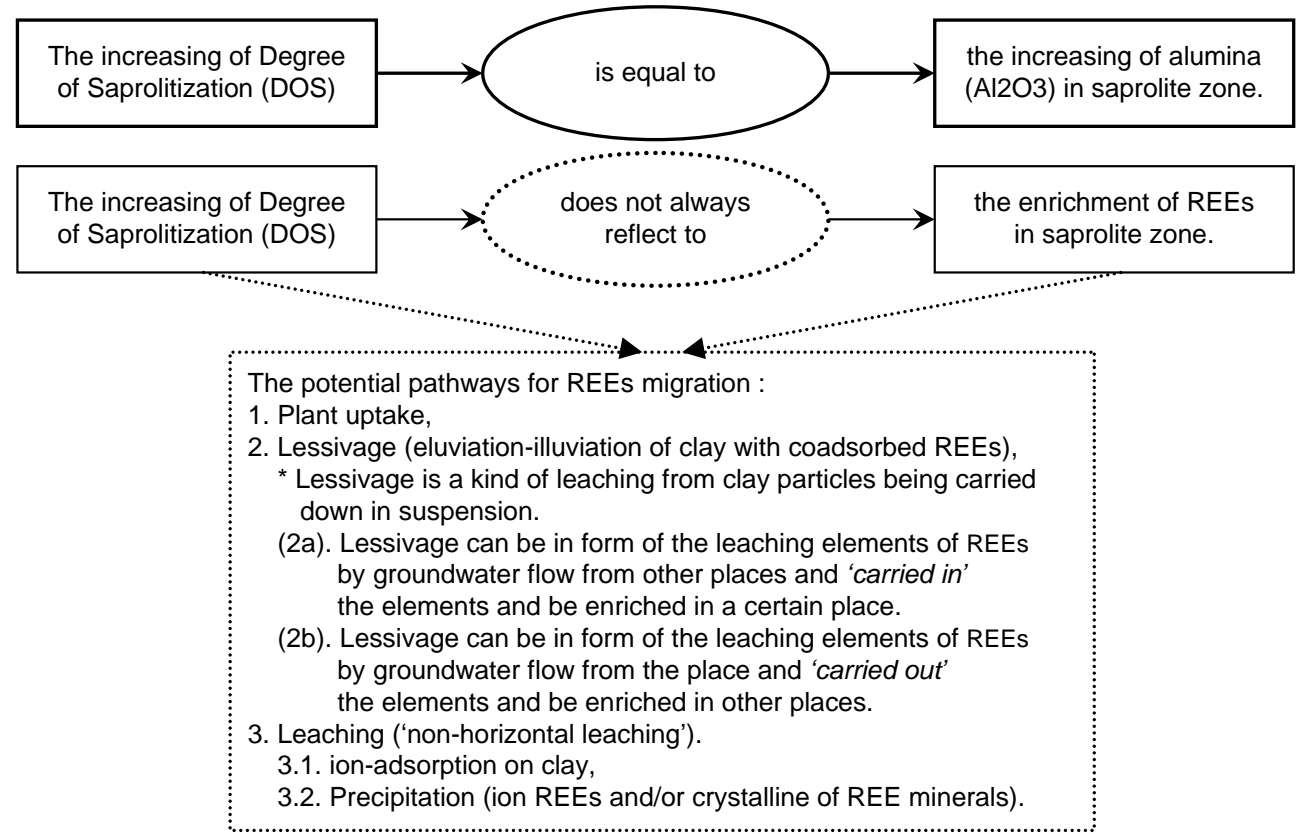

Figure 6: An illustration of the relationship between DOS and enrichment of REEs by weathering process and the potential pathways for REEs migration (modified after Aide and Aide, 2012)

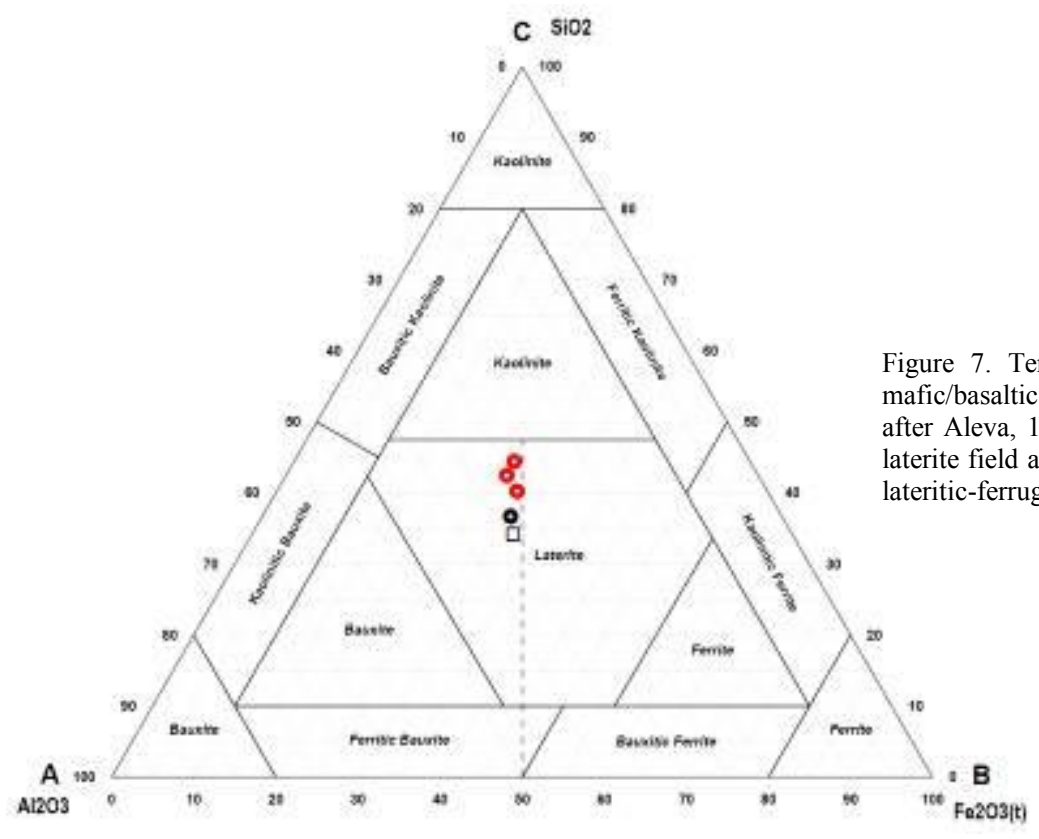

Figure 7. Ternary kaolinite-bauxite-ferrites classification for mafic/basaltic weathering rocks $\left(\mathrm{Al}_{2} \mathrm{O}_{3}-\mathrm{Fe}_{2} \mathrm{O}_{3}(\mathrm{t})-\mathrm{SiO}_{2}\right.$, in \%wt; 1994). The weathered samples of T01--T05 fall in field and after overlaying with Fig. 10 can be referred to teritic-ferruginous clay. Symbols in Fig. 8 

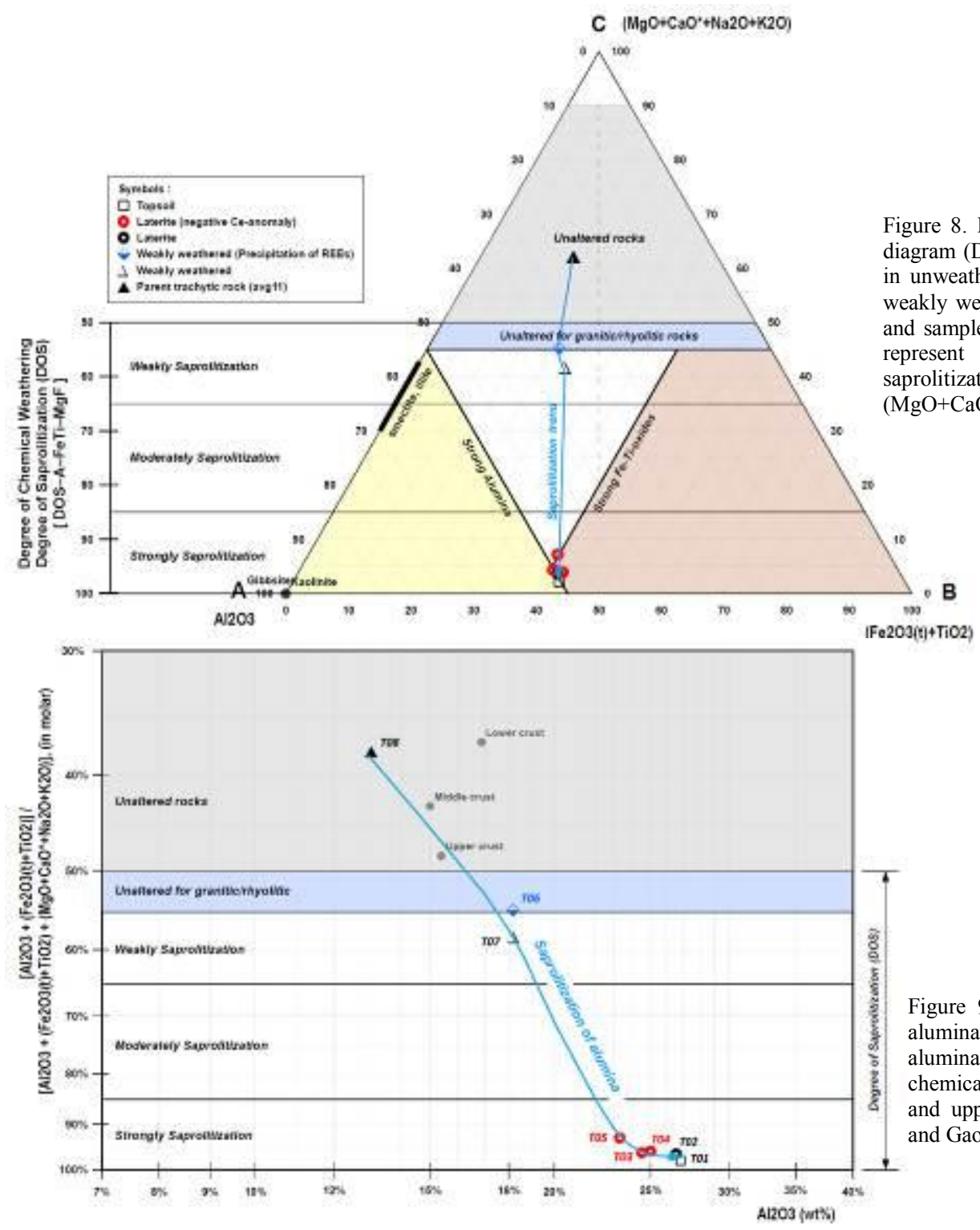

Figure 9. Plot in logarithmic binary DOS of alumina diagram shows the saprolitization of alumina by gradual increasing of 'degree of chemical weathering' (DOS). Lower, middle and upper crust data are taken from Rudnick and Gao, 2003. Symbols in Fig. 8

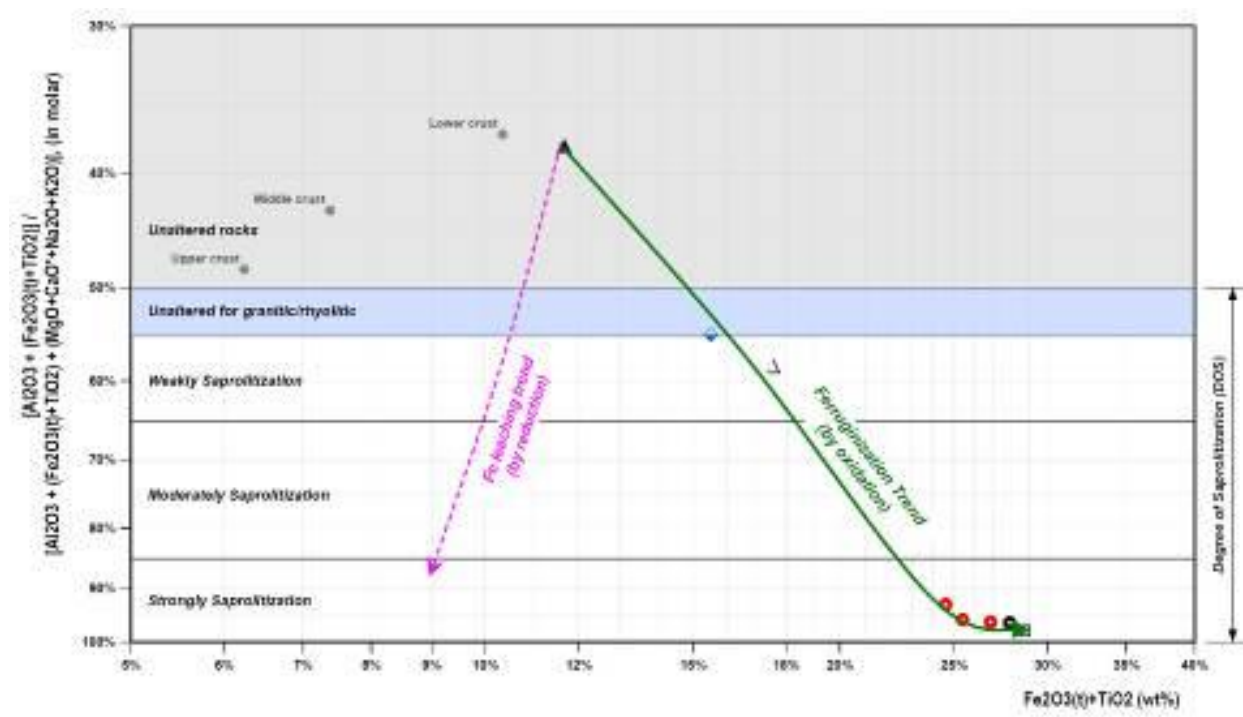

Figure 10. Plot in logarithmic binary DOS of Fe-Ti-oxides diagram (modified after McQueen, 2006) shows the gradual increase of Fe-Ti-oxides by ferruginization, and on the five laterite data do not show the occurrence of leaching of Fe. Symbols in Fig. 11 


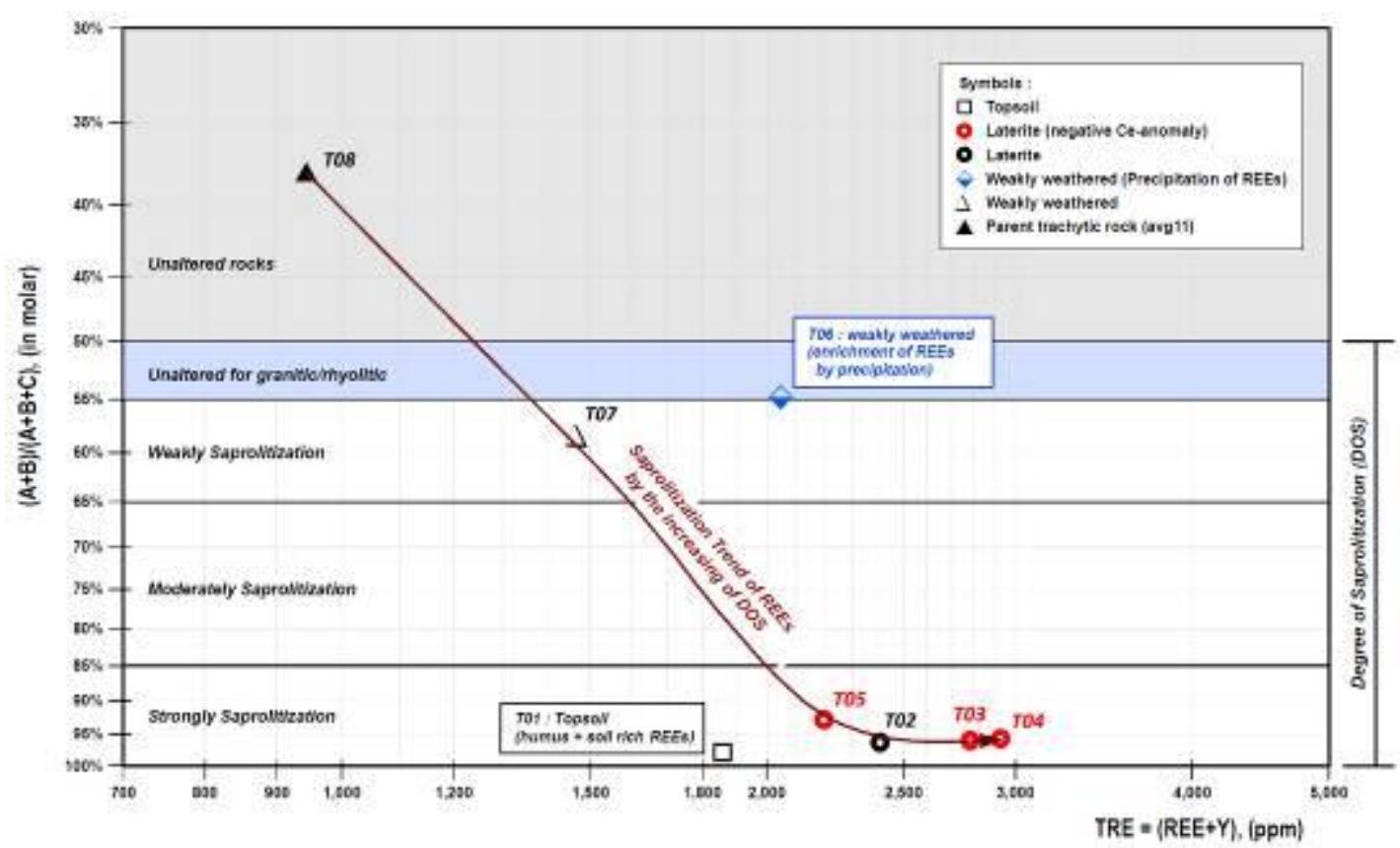

Figure 11. Plot in logarithmic binary DOS of REEs diagram shows the gradual increase of REEs by saprolitization along with the increase of DOS, sample of T06 is enrichment of REEs by precipitation and T01 is the topsoil. $\mathrm{A}=\mathrm{Al}_{2} \mathrm{O}_{3}, \mathrm{~B}=$ $\left(\mathrm{Fe}_{2} \mathrm{O}_{3}(\mathrm{t})+\mathrm{TiO}_{2}\right), \mathrm{C}=\left(\mathrm{MgO}+\mathrm{CaO} *+\mathrm{Na}_{2} \mathrm{O}+\mathrm{K}_{2} \mathrm{O}\right)$; (in molar)

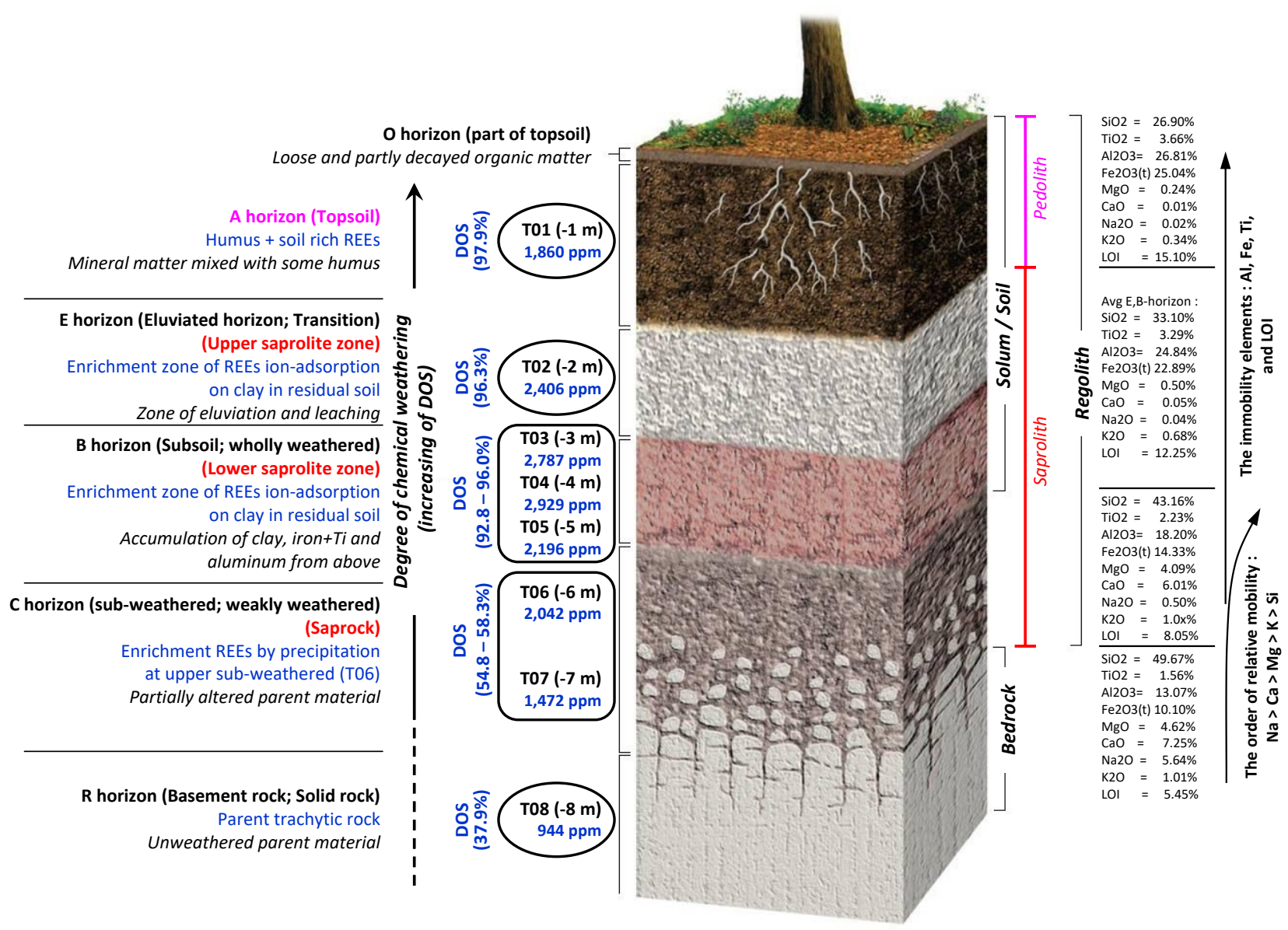

Figure 12a. Schematic model of REEs saprolite zone in regolith profile (modified after Wu et al., 1990 p.197; after Eggleton, 2001 p.78; after Wilford, 2011 p.2; after Cocker, 2012 p.8; after Hoshino et al., 2016 p.220; after Wang et al., 2017 p.320). The background image (not to scale) is copied from Lutgens and Tarbuck, 2012 (p.138) () Pearson Prentice Hall, Inc. 

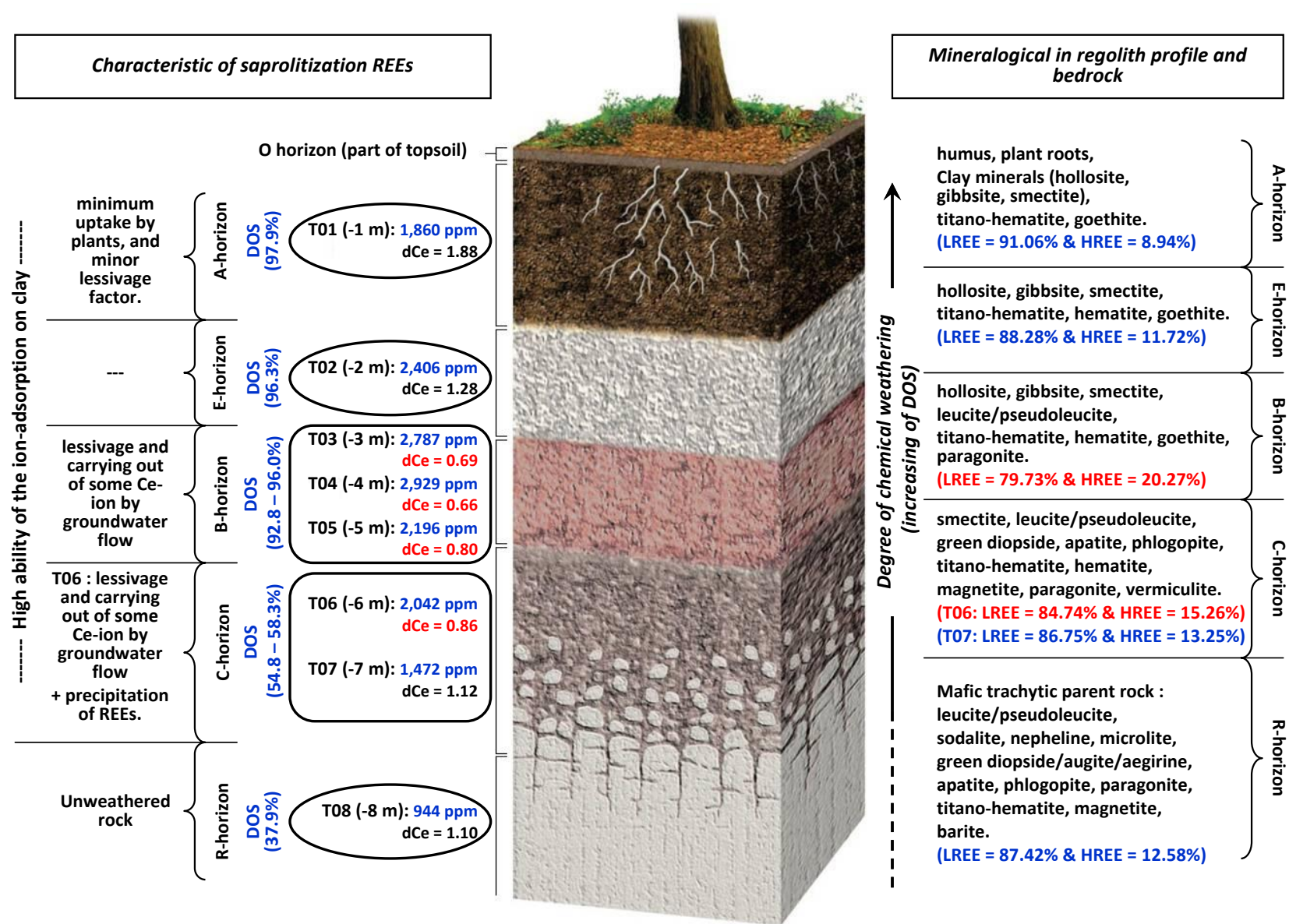

Figure 12b. Schematic model of saprolitization's characteristics of REEs, and minerals composition in regolith profile.

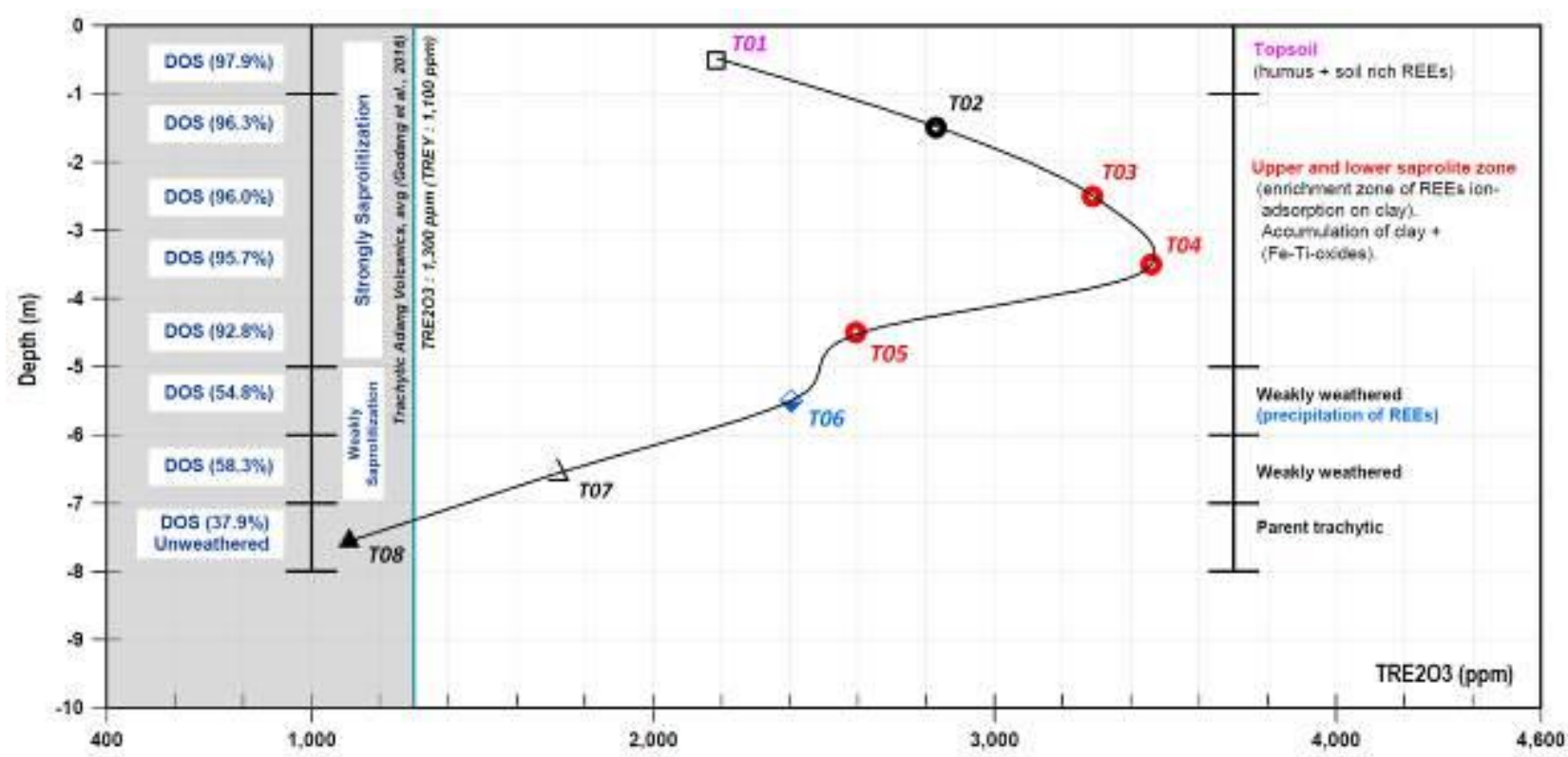

Figure 13. Variation of rare earth element in soil horizons diagram. Plot shows the idealized weathering profile of REEs ionadsorption on clay in saprolite zone. Symbols in Fig. 11 


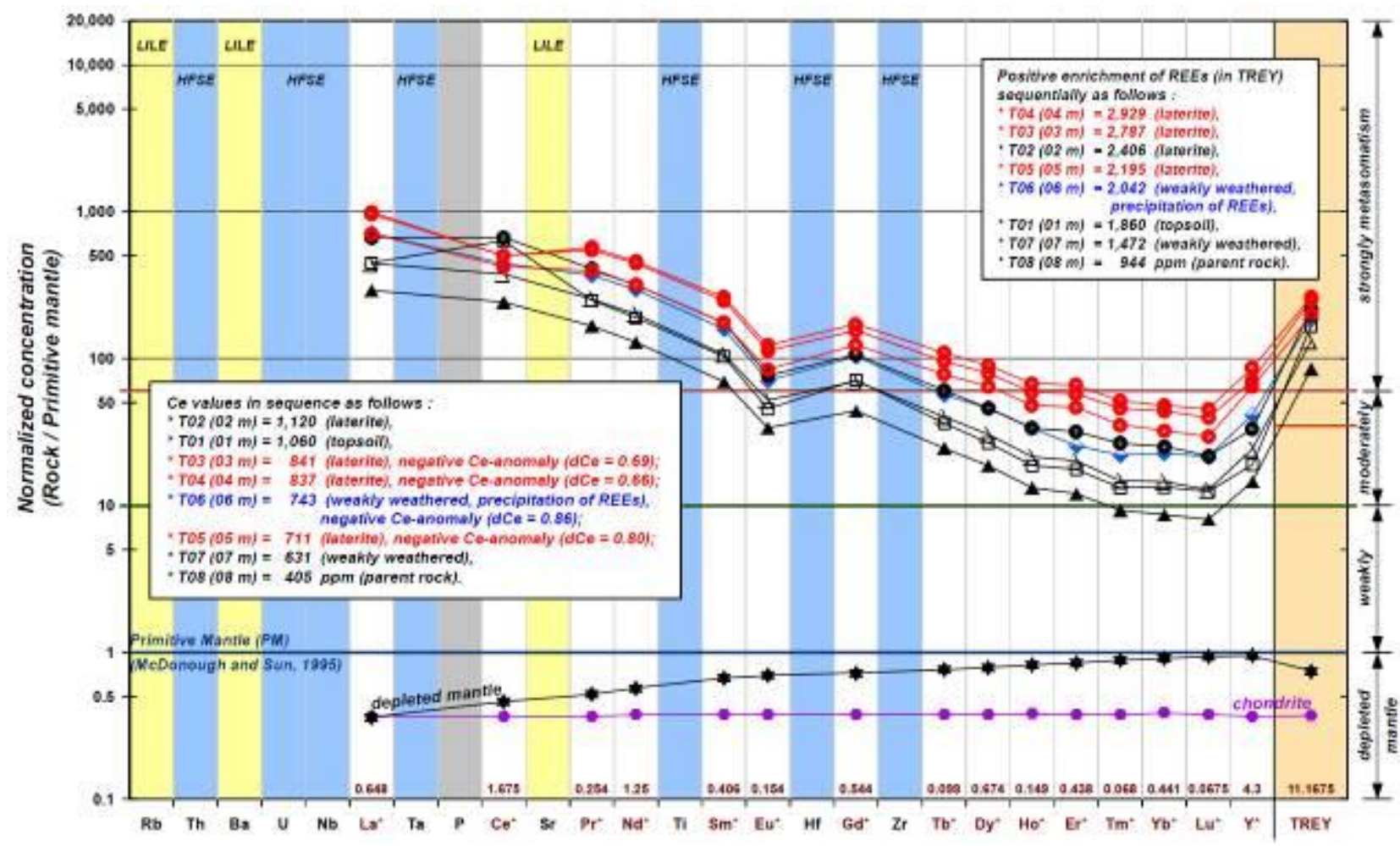

Figure 14. Normalized to Primitive Mantle of Rare Earth Elements (modified from Godang et al., 2016). The description of weakly-moderately-strongly mantle metasomatism is only used for the determination of the metasomatism level of mafic rocks. The plots show the positive enrichment of REEs (in TREY) in laterite profiles, topsoil and weakly weathered rocks. On the column of $\mathrm{Ce}^{*}$ displays the negative $\mathrm{Ce}$ anomaly $(\mathrm{dCe}<1.00)$ for laterite samples of T03--T06 and all of them have Eu negative anomaly $(\mathrm{dEu}<1.00)$. Symbols in Fig. 11. Primitive Mantle $(\mathrm{PM})$ values are taken from McDonough and Sun, 1995; Chondrite values are taken from Sun and McDonough, 1989; and Depleted Mantle (DM) from Salters and Stracke, 2004. 
Table 1. Major oxides (\%wt) and trace elements (ppm) of drill core \#65 samples from Adang Volcanics regolith on the elevation $336 \mathrm{~m}$.

\begin{tabular}{|c|c|c|c|c|c|c|c|c|}
\hline Sample No. & T01 & T02 & T03 & T04 & T05 & T06 & T07 & T08 (avg11) \\
\hline $\begin{array}{l}\text { Zoning of } \\
\text { drill core }\end{array}$ & Topsoil & Laterite & Laterite & Laterite & Laterite & $\begin{array}{l}\text { Weakly weathered } \\
\text { (precipitation of } \\
\text { REEs) }\end{array}$ & $\begin{array}{c}\text { Weakly } \\
\text { weathered }\end{array}$ & $\begin{array}{l}\text { Parent rock } \\
\quad \text { (avg11) }\end{array}$ \\
\hline Horizon & Hor-A & Hor-E & Hor-B & Hor-B & Hor-B & Hor-C & Hor-C & Hor-R \\
\hline Depth (m) & $1 \mathrm{~m}$ & $2 \mathrm{~m}$ & $3 \mathrm{~m}$ & $4 \mathrm{~m}$ & $5 \mathrm{~m}$ & $6 \mathrm{~m}$ & $7 \mathrm{~m}$ & $8-18 \mathrm{~m}$ \\
\hline $\mathrm{SiO} 2$ & 26.90 & 29.45 & 32.38 & 34.57 & 36.01 & 43.29 & 43.04 & 49.67 \\
\hline $\mathrm{TiO} 2$ & 3.66 & 3.61 & 3.28 & 3.41 & 2.85 & 2.20 & 2.27 & 1.56 \\
\hline $\mathrm{Al} 2 \mathrm{O} 3$ & 26.81 & 26.53 & 24.52 & 25.02 & 23.29 & 18.16 & 18.23 & 13.07 \\
\hline $\mathrm{Fe} 2 \mathrm{O} 3(\mathrm{t})$ & 25.04 & 24.26 & 23.56 & 21.99 & 21.75 & 13.33 & 15.34 & 10.10 \\
\hline $\mathrm{MnO}$ & 0.18 & 0.28 & 0.65 & 0.29 & 1.15 & 0.21 & 0.23 & 0.16 \\
\hline $\mathrm{MgO}$ & 0.24 & 0.39 & 0.39 & 0.42 & 0.80 & 4.30 & 3.88 & 4.62 \\
\hline $\mathrm{CaO}$ & 0.01 & 0.10 & 0.02 & 0.01 & 0.08 & 6.49 & 5.54 & 7.25 \\
\hline $\mathrm{Na} 2 \mathrm{O}$ & 0.02 & 0.08 & 0.03 & 0.04 & 0.03 & 0.32 & 0.67 & 5.65 \\
\hline $\mathrm{K} 2 \mathrm{O}$ & 0.34 & 0.45 & 0.67 & 0.75 & 0.86 & 1.04 & 1.04 & 1.01 \\
\hline $\mathrm{P} 2 \mathrm{O} 5$ & 0.67 & 0.68 & 0.76 & 0.70 & 0.65 & 1.06 & 0.81 & 0.72 \\
\hline LOI & 15.10 & 13.40 & 12.50 & 11.90 & 11.20 & 8.10 & 8.00 & 5.45 \\
\hline Total & 98.96 & 99.23 & 98.76 & 99.09 & 98.68 & 98.50 & 99.06 & 99.27 \\
\hline DOS \% & 97.88 & 96.31 & 96.05 & 95.70 & 92.84 & 54.79 & 58.30 & 37.91 \\
\hline $\operatorname{MIA}(0) \%$ & 97.66 & 95.92 & 95.65 & 95.25 & 92.19 & 52.30 & 55.89 & 35.65 \\
\hline CIA \% & 98.46 & 97.07 & 96.80 & 96.58 & 95.39 & 57.45 & 59.71 & 35.69 \\
\hline $\mathrm{La}$ & 292.00 & 433.00 & 624.00 & 645.00 & 461.00 & 462.00 & 287.00 & 188.36 \\
\hline $\mathrm{Ce}$ & $1,060.00$ & $1,120.00$ & 841.00 & 837.00 & 711.00 & 743.00 & 631.00 & 405.36 \\
\hline $\mathrm{Pr}$ & 63.40 & 104.00 & 139.00 & 145.00 & 101.00 & 93.60 & 64.70 & 42.43 \\
\hline $\mathrm{Nd}$ & 237.00 & 396.00 & 554.00 & 575.00 & 398.00 & 368.00 & 251.00 & 161.18 \\
\hline $\mathrm{Sm}$ & 41.80 & 71.30 & 101.00 & 106.00 & 70.80 & 64.40 & 43.40 & 28.28 \\
\hline $\mathrm{Eu}$ & 7.00 & 11.80 & 17.40 & 19.00 & 13.00 & 10.90 & 8.00 & 5.21 \\
\hline Gd & 38.70 & 57.80 & 84.40 & 93.40 & 67.30 & 56.10 & 38.20 & 24.05 \\
\hline $\mathrm{Tb}$ & 3.59 & 6.03 & 9.49 & 10.80 & 7.70 & 5.60 & 3.96 & 2.43 \\
\hline Dy & 18.00 & 31.00 & 53.60 & 60.60 & 43.70 & 30.90 & 20.60 & 12.53 \\
\hline Ho & 2.80 & 5.00 & 8.80 & 10.10 & 7.20 & 5.00 & 3.20 & 1.96 \\
\hline Er & 7.70 & 13.90 & 25.20 & 29.00 & 20.40 & 11.20 & 8.80 & 5.27 \\
\hline $\mathrm{Tm}$ & 0.90 & 1.80 & 3.10 & 3.50 & 2.40 & 1.50 & 1.00 & 0.63 \\
\hline $\mathrm{Yb}$ & 5.90 & 11.10 & 19.30 & 21.10 & 14.30 & 10.00 & 6.40 & 3.83 \\
\hline $\mathrm{Lu}$ & 0.84 & 1.47 & 2.67 & 3.06 & 1.99 & 1.45 & 0.86 & 0.54 \\
\hline $\mathrm{Y}$ & 81.00 & 142.00 & 304.00 & 371.00 & 276.00 & 179.00 & 104.00 & 62.35 \\
\hline TRE (TREY) & $1,860.63$ & $2,406.20$ & $2,786.96$ & $2,929.56$ & $2,195.79$ & $2,042.65$ & $1,472.12$ & 944.43 \\
\hline TRExOy & $2,247.20$ & $2,895.08$ & $3,339.73$ & $3,512.67$ & $2,637.58$ & $2,451.43$ & $1,769.75$ & $1,135.05$ \\
\hline TRE2O3 & $2,184.18$ & $2,827.04$ & $3,286.20$ & $3,459.09$ & $2,592.95$ & $2,405.32$ & $1,731.17$ & $1,110.23$ \\
\hline $\mathrm{dEu}$ & 0.53 & 0.56 & 0.57 & 0.58 & 0.57 & 0.55 & 0.60 & 0.61 \\
\hline $\mathrm{dCe}$ & 1.88 & 1.28 & 0.69 & 0.66 & 0.80 & 0.86 & 1.12 & 1.10 \\
\hline
\end{tabular}

Note:

- DOS $=$ Degree Of Saprolitization diagram (new created in this paper). The diagram is using four base weathering elements $(\mathrm{MgO}+\mathrm{CaO} *+\mathrm{Na} 2 \mathrm{O}+\mathrm{K} 2 \mathrm{O})$ and $\mathrm{Al}_{2} \mathrm{O}_{3}, \mathrm{Fe}_{2} \mathrm{O}_{3}(\mathrm{t}), \mathrm{TiO}_{2}$, all in molar. The addition of $\mathrm{TiO} 2$ is used to cover the existence of abundance TiO2 in anorogenic protoliths.

- $\quad \mathrm{CIA}=$ Chemical Index of Alteration diagram for felsic weathering (e.g. granitic or rhyolitic)(Nesbitt and Young, 1984). The diagram is using three base weathering elements $\left(\mathrm{CaO}^{*}+\mathrm{Na} 2 \mathrm{O}+\mathrm{K} 2 \mathrm{O}\right)$ and $\mathrm{Al}_{2} \mathrm{O}_{3}$ (in molar), where $\mathrm{CaO}^{*}$ represents CaO incorporated into silicate minerals .

- $\quad \operatorname{MIA}(\mathrm{o})=$ Mafic Index of Alteration (oxidized)(Nesbitt and Wilson, 1992; modified by Babechuk et al., 2014). The diagram is using four base weathering elements $(\mathrm{CaO} *+\mathrm{Na} 2 \mathrm{O}+\mathrm{K} 2 \mathrm{O}$ and $\mathrm{MgO}), \mathrm{Al}_{2} \mathrm{O}_{3}, \mathrm{Fe}_{2} \mathrm{O}_{3}(\mathrm{t})$ (in molar) for orogenic belt tectonic setting.

- Molecular weight of $\mathrm{MgO}=40.3044 \mathrm{gr} / \mathrm{gmol}, \mathrm{CaO}=56.077 \mathrm{gr} / \mathrm{gmol}, \mathrm{Na} 2 \mathrm{O}=61.979 \mathrm{gr} / \mathrm{gmol}, \mathrm{K} 2 \mathrm{O}=94.196 \mathrm{gr} / \mathrm{gmol}, \mathrm{Al} 2 \mathrm{O} 3=101.961$ $\mathrm{gr} / \mathrm{gmol}, \mathrm{Fe} 2 \mathrm{O} 3(\mathrm{t})=159.6882 \mathrm{gr} / \mathrm{gmol}, \mathrm{TiO} 2=79.8658 \mathrm{gr} / \mathrm{gmol}$. 
Table 2. Conversion of TRE to TRExOy, and TRE2O3; ratio laterite/parent rock and distribution of LREE \& HREE (in ppm).

\begin{tabular}{|c|c|c|c|c|c|c|c|c|c|c|c|c|c|c|c|c|}
\hline Sample No. & La & $\mathrm{Ce}$ & Pr & Nd & Sm & Eu & Gd & Tb & Dy & Ho & Er & Tm & $\mathbf{Y b}$ & Lu & $\mathbf{Y}$ & TRE \\
\hline T01 & 292.00 & $1,060.00$ & 63.40 & 237.00 & 41.80 & 7.00 & 38.70 & 3.59 & 18.00 & 2.80 & 7.70 & 0.90 & 5.90 & 0.84 & 81.00 & $1,860.63$ \\
\hline T02 & 433.00 & $1,120.00$ & 104.00 & 396.00 & 71.30 & 11.80 & 57.80 & 6.03 & 31.00 & 5.00 & 13.90 & 1.80 & 11.10 & 1.47 & 142.00 & $2,406.20$ \\
\hline T03 & 624.00 & 841.00 & 139.00 & 554.00 & 101.00 & 17.40 & 84.40 & 9.49 & 53.60 & 8.80 & 25.20 & 3.10 & 19.30 & 2.67 & 304.00 & $2,786.96$ \\
\hline T04 & 645.00 & 837.00 & 145.00 & 575.00 & 106.00 & 19.00 & 93.40 & 10.80 & 60.60 & 10.10 & 29.00 & 3.50 & 21.10 & 3.06 & 371.00 & 929.56 \\
\hline T05 & 461.00 & 711.00 & 101.00 & 398.00 & 70.80 & 13.00 & 67.30 & 7.70 & 43.70 & 7.20 & 20.40 & 2.40 & 14.30 & 1.99 & 276.00 & $2,195.79$ \\
\hline T06 & 462.00 & 743.00 & 93.60 & 368.00 & 4.40 & 10.90 & 56.10 & 5.60 & 30.90 & 5.00 & 11.20 & 1.50 & 10.00 & 1.45 & 179.00 & $2,042.65$ \\
\hline T07 & 287.00 & 631.00 & 64.70 & 251.00 & 43.40 & 8.00 & 38.20 & 3.96 & 20.60 & 3.20 & 8.80 & 1.00 & 6.40 & 0.86 & 104.00 & $1,472.12$ \\
\hline T08 & 188.36 & 405.36 & 42.43 & 161.18 & 28.28 & 5.21 & 24.05 & 2.43 & 12.53 & 1.96 & 5.27 & 0.63 & 3.83 & 0.54 & 62.35 & 944.43 \\
\hline
\end{tabular}

\begin{tabular}{|c|c|c|c|c|c|c|c|c|c|c|c|c|c|c|c|c|}
\hline Sample No. & La2O3 & $\mathrm{CeO2}$ & Pr6011 & Nd2O3 & Sm203 & Eu2O3 & Gd2O3 & Tb407 & Dy203 & Ho2O3 & Er2O3 & Tm2O3 & Yb2O3 & Lu2O3 & Y2O3 & TRExOy \\
\hline T01 & 342.44 & $1,302.08$ & 76.60 & 276.43 & 48.47 & 8.11 & 4.61 & 4.22 & 20.66 & 3.21 & 8.80 & 1.03 & 6.72 & 0.96 & 102.87 & $2,247.20$ \\
\hline T02 & 7.80 & $1,375.78$ & 125.65 & 461.89 & 82.68 & 13.66 & 6.62 & 7.09 & 35.58 & 5.73 & 15.89 & 2.06 & 12.64 & 1.67 & 80.34 & 895.08 \\
\hline T03 & 1.79 & $1,033.06$ & 167.93 & 646.18 & 117.12 & 20.15 & 7.28 & 11.16 & 61.52 & 10.08 & 28.82 & 3.54 & 21.98 & 3.04 & 86.09 & 9.73 \\
\hline T04 & 756.42 & $1,028.15$ & 175.18 & 670.67 & 122.92 & 22.00 & 107.66 & 12.70 & 69.55 & 11.57 & 33.16 & 4.00 & 24.03 & 3.48 & 71.18 & $3,512.67$ \\
\hline T05 & 540.63 & 873.38 & 122.02 & 464.22 & 82.10 & 15.05 & 77.57 & 9.06 & 50.15 & 8.25 & 23.33 & 2.74 & 16.28 & 2.26 & 350.53 & $2,637.58$ \\
\hline T06 & 541.80 & 912.68 & 113.08 & 429.23 & 74.68 & 12.62 & 4.66 & 6.59 & 35.46 & 5.73 & 12.81 & 1.71 & 11.39 & 1.65 & 227.33 & $2,451.43$ \\
\hline T07 & 336.58 & 775.11 & 78.17 & 292.76 & 50.33 & 9.26 & 44.03 & 4.66 & 23.64 & 3.67 & 10.06 & 1.14 & 7.29 & 0.98 & 132.08 & $1,769.75$ \\
\hline T08 & 220.90 & 497.94 & 51.26 & 188.00 & 32.80 & 6.03 & 27.73 & 2.86 & 14.38 & 2.25 & 6.03 & 0.72 & 4.36 & 0.61 & 79.19 & $1,135.05$ \\
\hline
\end{tabular}

\begin{tabular}{|c|c|c|c|c|c|c|c|c|c|c|c|c|c|c|c|c|}
\hline Sample No. & La2O3 & $\mathrm{Ce} 2 \mathrm{O} 3$ & Pr2O3 & $\mathrm{Nd2O3}$ & Sm2O3 & Eu2O3 & Gd2O3 & Tb2O3 & Dy2O3 & Ho2O3 & Er2O3 & Tm2O3 & Yb2O3 & $\mathrm{Lu2O3}$ & Y2O3 & TRE2O3 \\
\hline T01 & 342.45 & $1,241.55$ & 74.20 & 276.43 & 48.47 & 8.11 & 44.61 & 4.13 & 20.66 & 3.21 & 8.80 & 1.03 & 6.72 & 0.96 & 102.86 & $2,184.18$ \\
\hline $\mathrm{T} 02$ & 7.81 & $1,311.83$ & .71 & 1.89 & 2.68 & 56 & 6.62 & 6.94 & 5.58 & 5.73 & 15.89 & 2.06 & 2.64 & 1.67 & 3 & 04 \\
\hline T03 & 731.81 & 985.04 & 2.67 & 46.18 & 12 & 5 & 7.28 & 10.92 & 1.52 & 10.08 & 8.82 & 3.54 & 98 & 3.04 & 86.06 & 20 \\
\hline T04 & 756.43 & 0.36 & 169.70 & 70.67 & 122.92 & 22.00 & 107.65 & 12.43 & 9.55 & 11.57 & 3.16 & 4.00 & 4.03 & 3.48 & 471.14 & 59.09 \\
\hline T05 & 540.65 & 832.78 & 118.20 & 64.22 & 2.10 & 15.05 & 77.57 & 8. & 0.15 & 8.25 & 3.33 & 2.74 & 6.28 & 2.26 & 50.50 & $2,592.95$ \\
\hline T06 & 541.82 & 870.26 & 109.54 & 429.23 & 4.68 & 12.62 & 4.66 & 6.45 & 5.46 & 5.73 & 12.81 & 1.71 & 11.39 & 1.65 & 227.32 & $2,405.32$ \\
\hline T07 & 336.58 & 739.07 & 75.72 & 292.76 & 0.33 & 9.26 & 44.03 & 4.56 & 23.64 & 3.67 & 10.06 & 1.14 & 7.29 & 0.98 & 132.07 & $1,731.17$ \\
\hline T08 & 220.91 & 474.79 & 49.65 & 188.00 & 32.80 & 6.03 & 27.73 & 2.80 & 14.38 & 2.25 & 6.03 & 0.72 & 4.36 & 0.61 & 79.19 & $1,110.23$ \\
\hline
\end{tabular}

\begin{tabular}{|c|r|r|r|r|r|r|r|r|r|}
\hline Major oxides (\%) & \multicolumn{1}{|c|}{ SiO2 } & \multicolumn{1}{|c|}{ TiO2 } & Al2O3 & Fe2O3(t) & MgO & \multicolumn{1}{c|}{ CaO } & Na2O & K2O & \multicolumn{1}{c|}{ LOI } \\
\hline T08 (Parent rock) & 49.67 & 1.56 & 13.07 & 10.10 & 4.62 & 7.25 & 5.65 & 1.01 & 5.45 \\
\hline T02-T05 (laterite) & 33.10 & 3.29 & 24.84 & 22.89 & 0.50 & 0.05 & 0.05 & 0.68 & 12.25 \\
\hline $\begin{array}{c}\text { Ratio (Laterite / } \\
\text { Parent rock) }\end{array}$ & 0.67 & 2.10 & 1.90 & 2.27 & 0.11 & 0.01 & 0.01 & 0.68 & 2.25 \\
\hline
\end{tabular}

\begin{tabular}{|c|c|c|c|c|c|c|c|c|c|c|c|c|c|c|c|c|}
\hline REEs (ppm) & La & $\mathrm{Ce}$ & $\operatorname{Pr}$ & Nd & Sm & Eu & Gd & Tb & Dy & Ho & Er & Tm & $\mathbf{Y b}$ & Lu & $\mathbf{Y}$ & TRE \\
\hline T08 (Parent rock) & 188.36 & 405.36 & 42.43 & 161.18 & 28.28 & 5.21 & 24.05 & 2.43 & 12.53 & 1.96 & 5.27 & 0.63 & 3.83 & 0.54 & 62.35 & 944.43 \\
\hline T02-T05 (laterite) & 540.75 & 877.25 & 122.25 & 480.75 & 87.28 & 15.30 & 75.73 & 8.51 & 47.23 & 7.78 & 22.13 & 2.70 & 16.45 & 2.30 & 273.25 & $2,579.63$ \\
\hline $\begin{array}{c}\text { Ratio (Laterite / } \\
\text { Parent rock) }\end{array}$ & 2.87 & 2.16 & 2.88 & 2.98 & 3.09 & 2.94 & 3.15 & 3.50 & 3.77 & 3.96 & 4.20 & 4.30 & 4.30 & 4.25 & 4.38 & 2.73 \\
\hline Parent rock & La & $\mathrm{Ce}$ & Pr & Nd & Sm & Eu & Gd & Tb & Dy & Ho & Er & Tm & Yb & Lu & $\mathbf{Y}$ & TRE \\
\hline T08 (ppm) & 188.36 & 405.36 & 42.43 & 161.18 & 28.28 & 5.21 & 24.05 & 2.43 & 12.53 & 1.96 & 5.27 & 0.63 & 3.83 & 0.54 & 62.35 & 944.43 \\
\hline$\%$ & $19.94 \%$ & $42.92 \%$ & $4.49 \%$ & $17.07 \%$ & $2.99 \%$ & $0.55 \%$ & $2.55 \%$ & $0.26 \%$ & $1.33 \%$ & $0.21 \%$ & $0.56 \%$ & $0.07 \%$ & $0.41 \%$ & $0.06 \%$ & $6.60 \%$ & $100 \%$ \\
\hline & \multicolumn{5}{|c|}{ LREE $=87.42 \%$} & \multicolumn{10}{|c|}{ HREE $=12.58 \%$} & \\
\hline
\end{tabular}

\begin{tabular}{|c|c|c|c|c|c|c|c|c|c|c|c|c|c|c|c|c|}
\hline T01--T05 (avg) & La & $\mathrm{Ce}$ & Pr & Nd & Sm & Eu & Gd & Tb & Dy & Ho & Er & Tm & $\mathbf{Y b}$ & Lu & $\mathbf{Y}$ & TRE \\
\hline Laterite $(\mathrm{ppm})$ & 491.00 & 913.80 & 110.48 & 432.00 & 78.18 & 13.64 & 68.32 & 7.52 & 41.38 & 6.78 & 19.24 & 2.34 & 14.34 & 2.01 & 234.80 & $2,435.83$ \\
\hline$\%$ & $20.16 \%$ & $37.51 \%$ & $4.54 \%$ & $17.74 \%$ & $3.21 \%$ & $0.56 \%$ & $2.80 \%$ & $0.31 \%$ & $1.70 \%$ & $0.28 \%$ & $0.79 \%$ & $0.10 \%$ & $0.59 \%$ & $0.08 \%$ & $9.64 \%$ & $100 \%$ \\
\hline & \multicolumn{5}{|c|}{ LREE $=83.15 \%$} & & \\
\hline
\end{tabular}

Note: $\mathrm{dEu}=\mathrm{Eu} / \mathrm{Eu}^{*}=$ the value of Eu anomaly calculated by the formula $\mathrm{Eu} / \mathrm{Eu}^{*}=\left(\mathrm{Eu}_{\mathrm{N}}\right) /\left[\left(\mathrm{Sm}_{\mathrm{N}} \mathrm{xGd}\right)^{\wedge}(1 / 2)\right]$ from Taylor and McLennan, 1985 ; $\mathrm{dCe}$ $=\mathrm{Ce} / \mathrm{Ce}^{*}=$ the value of $\mathrm{Ce}$ anomaly calculated by the formula $\left.\mathrm{Ce} / \mathrm{Ce} *=\left(\mathrm{Ce}_{\mathrm{N}}\right) /\left[\left(\mathrm{La}_{\mathrm{N}} \mathrm{XPr}\right)_{\mathrm{N}}\right)^{\wedge}(1 / 2)\right]$ from Worrall and Pearson, 2001 ; $\mathrm{N}$ is chondrite value from Sun and McDonough, 1989. 